\title{
Temperature-Dependent Wsm1 and Wsm2 Gene-Specific Blockage of Viral Long-Distance Transport Provides Resistance to Wheat streak mosaic virus and Triticum mosaic virus in Wheat
}

\author{
Satyanarayana Tatineni,, ${ }^{1}$ Everlyne N. Wosula, ${ }^{2}$ Melissa Bartels, ${ }^{1}$ Gary L. Hein, ${ }^{2}$ and Robert A. Graybosch ${ }^{3}$ \\ ${ }^{1}$ United States Department of Agriculture-Agricultural Research Service (USDA-ARS) and Department of Plant Pathology, \\ University of Nebraska-Lincoln, Lincoln, NE 68583, U.S.A.; ${ }^{2}$ Department of Entomology, University of Nebraska-Lincoln; and \\ ${ }^{3}$ USDA-ARS and Department of Agronomy and Horticulture, University of Nebraska-Lincoln
}

Accepted 18 August 2016.

\begin{abstract}
Wheat streak mosaic virus (WSMV) and Triticum mosaic virus (TriMV) are economically important viral pathogens of wheat. Wheat cvs. Mace, carrying the Wsm1 gene, is resistant to WSMV and TriMV, and Snowmass, with Wsm2, is resistant to WSMV. Viral resistance in both cultivars is temperature sensitive and is effective at $18^{\circ} \mathrm{C}$ or below but not at higher temperatures. The underlying mechanisms of viral resistance of Wsm1 and Wsm2, nonallelic single dominant genes, are not known. In this study, we found that fluorescent protein-tagged WSMV and TriMV elicited foci that were approximately similar in number and size at 18 and $24^{\circ} \mathrm{C}$, on inoculated leaves of resistant and susceptible wheat cultivars. These data suggest that resistant wheat cultivars at $18^{\circ} \mathrm{C}$ facilitated efficient cell-to-cell movement. Additionally, WSMV and TriMV efficiently replicated in inoculated leaves of resistant wheat cultivars at $18^{\circ} \mathrm{C}$ but failed to establish systemic infection, suggesting that Wsm1- and Wsm2-mediated resistance debilitated viral long-distance transport. Furthermore, we found that neither virus was able to enter the leaf sheaths of inoculated leaves or crowns of resistant wheat cultivars at $18^{\circ} \mathrm{C}$ but both were able to do so at $24^{\circ} \mathrm{C}$. Thus, wheat cvs. Mace and Snowmass provide resistance at the long-distance movement stage by specifically blocking virus entry into the vasculature. Taken together, these data suggest that both Wsm1 and Wsm2 genes similarly confer virus resistance by temperature-dependent impairment of viral long-distance movement.
\end{abstract}

Viruses contain a relatively small genetic coding capacity and, hence, must successfully interact with plant machinery for replication, movement, and spread. In the process of these interactions, sometimes viruses induce disease in plants. In turn, plants have developed diverse mechanisms to combat pathogens, including viruses (Mandadi and Scholthof 2013). One of several

Mention of trade names or commercial products in this publication is solely for the purpose of providing specific information and does not imply recommendation or endorsement by the U.S. Department of Agriculture.

Current address for E. N. Wosula: International Institute of Tropical Agriculture, P.O Box 34441, Dar es Salaam, Tanzania.

Corresponding author: S Tatineni; E-mail: satya.tatineni@ars.usda.gov

This article is in the public domain and not copyrightable. It may be freely reprinted with customary crediting of the source. The American Phytopathological Society, 2016. mechanisms employed by plants to defend against viral infections is dominant resistance $(R)$ genes encoding nucleotide binding site leucine-rich repeat proteins (NB-LRR) (de Ronde et al. 2014; Fraser 1990). The $R$ gene-mediated resistance operates on the basis of the gene-for-gene model, in which a host $R$ geneencoded protein will recognize a pathogen-derived avirulence factor (Jones and Dangl 2006). The $R$ gene response in the majority of pathosystems results in expression of a hypersensitive response (HR) or extreme resistance (ER) (Bendahmane et al. 1999; Hajimorad et al. 2005, 2006; Moffett 2009). In both HR and ER responses, pathogens are restricted to the site of entry, thus preventing systemic spread. Additionally, several unusual $R$ genes differ from the classical NB-LRR class $R$ gene-mediated HR or ER mode of action. The nonconventional $R$ genes include RTM1, RTM2, and RTM3 genes in Arabidopsis against Tobacco etch virus (TEV) (Chisholm et al. 2001; Cosson et al. 2010; Whitham et al. 2000), Scmv2 in maize against Sugarcane mosaic virus (Ingvardsen et al. 2010), Rsv4 in soybean against Soybean mosaic virus (SMV) (Saghai Maroof et al. 2010), and Tm-1 in tomato against Tomato mosaic virus (ToMV) (Ishibashi et al. 2007). The above $R$ genes provide resistance by restricting viral replication or cell-to-cell and long-distance movement or a combination thereof (Chisholm et al. 2001; Kang et al. 2005a; Khatabi et al. 2012; Mahajan et al. 1998).

Candidate gene approaches have identified a large number of natural recessive $R$ genes against several plant viruses (Revers and Nicaise 2014; Truniger and Aranda 2009; Wang and Krishnaswamy 2012). Most of these recessive genes encode the eukaryotic translation initiation factor $4 \mathrm{E}$ (eIF4E) or its isomers, with mutation of a few amino acids that prevent physical interaction with the virus-encoded proteins without being lethal to plants. Though recessive resistance appears to be more frequent for potyviruses, it has also been observed for other viruses such as bymo-, cucumo-, ipomo-, sobemo-, carmo-, and waikiviruses (Wang and Krishnaswamy 2012). In potyviruses, interactions between host translation initiation factors and virus-encoded VPg are crucial for infection of plants (Kang et al. 2005b; Wittmann et al. 1997; Yeam et al. 2007). A few amino acid mutations within eIF4E and eIF(iso)4E provided resistance to potyvirus infection in a range of plants, primarily due to debilitating interactions between translation initiation factors and VPg (Revers and Nicaise 2014; Wang and Krishnaswamy 2012; Wittmann et al. 1997).

Successful infection of a plant by a virus requires a series of interactions between host and viral factors for replication, 
suppression of host defense, and movement (Harries and Ding 2011; Heinlein 2015; Nelson and Citovsky 2005; Voinnet et al. 1999). Systemic spread of viruses throughout plants occurs mainly through successive cycles of cell-to-cell and long-distance movement. Virus movement in plants is an active process mediated by virus-encoded movement proteins through interactions with host factors (Benitez-Alfonso et al. 2010; Harries and Ding 2011; Waigmann et al. 2004; Wang et al. 1998; XoconostleCázares et al. 2000). Interrupting these interactions by silencing or mutation of host factors has been postulated for recessively inherited 'passive resistance' in plants (Fraser 1990).

Wheat streak mosaic virus (WSMV) and Triticum mosaic virus (TriMV) are the type species of genera Tritimovirus (Stenger et al. 1998) and Poacevirus (Fellers et al. 2009; Tatineni et al. 2009), respectively, in the family Potyviridae. Both viruses are transmitted mechanically by rub-inoculation at approximately $100 \%$ and are efficiently transmitted by the wheat curl mite Aceria tosichella Keifer (McMechan et al. 2014; Seifers et al. 2009; Slykhuis 1955). WSMV is an economically important wheat virus in the Great Plains region of the United States, with estimated annual yield losses of 2 to $5 \%$ with $100 \%$ losses in localized infections (Brakke 1987; French and Stenger 2004). TriMV, a recently discovered virus, is widespread in the Great Plains region (Burrows et al. 2009; Byamukama et al. 2013; Seifers et al. 2008). The impact of TriMV on yield loss is not known; however, WSMV and TriMV interact synergistically in coinfected wheat, causing increased disease severity and yield losses (Byamukama et al. 2012, 2014; Tatineni et al. 2010). WSMV and TriMV virions contain single 9.4- and 10.3-kilobase (kb) genomic RNA, respectively, encoding a single open reading frame (ORF) of about 350-kDa polyproteins. The polyproteins of both WSMV and TriMV are likely processed into mature proteins by three virus-encoded proteinases, P1, HC-Pro, and NIa-Pro. The P1 proteins of WSMV and TriMV have been identified as suppressors of RNA silencing and enhancers of pathogenicity (Tatineni et al. 2012; Young et al. 2012). HC-Pro of WSMV is dispensable for systemic infection of wheat but is required for mite transmission (Stenger et al. 2005a and b, 2006). Independent of its function for virion production, WSMV coat protein $(\mathrm{CP})$ is identified as a multifunctional protein required for cell-to-cell movement and is a long-distance transport determinant for extension of virus host range (Tatineni and French 2014; Tatineni et al. 2011b, 2014). Additionally, P3N-PIPO is also implicated in cell-to-cell movement of WSMV (Choi et al. 2005).

In wheat, genetic resistance has been used for management of viral diseases by deployment of nonallelic Wsm1 or Wsm2 genes (Graybosch et al. 2009; Lu et al. 2011). Wsml, a single dominant $R$ gene present in wheat cultivar Mace, was originally transferred from intermediate wheatgrass [Thinopyrum intermedium (Host) Barkworth \& D. R. Dewey] (Graybosch et al. 2009). Wsm2, a single dominant $R$ gene of unknown origin, was originally identified in wheat germplasm line CO960293-2 (Haley et al. 2002) and has been incorporated into wheat cvs. Snowmass (Haley et al. 2011) and RonL (Seifers et al. 2007). Wheat cv. Mace is genetically near homogeneous for virus resistance, while 'Snowmass' is heterogeneous in its reaction to WSMV, as approximately $20 \%$ of the plants remain susceptible to WSMV at $18^{\circ} \mathrm{C}$ (Haley et al. 2011). Both Wsml and Wsm2 are temperature-sensitive genes conferring high-levels of resistance to WSMV and TriMV (Wsml) and WSMV (Wsm2), at or below $18^{\circ} \mathrm{C}$ but are ineffective at higher temperatures (Graybosch et al. 2009; Haley et a. 2011; Seifers et al. 1995, 2007; Tatineni et al. 2010). Although the molecular basis for dominant genetic resistance is understood for a few virus-host systems, none include cereals (de Ronde et al. 2014; Kang et al. 2005a). The mechanisms of temperature-dependent virus resistance of the Wsm1 and Wsm2 genes in wheat cvs. Mace and Snowmass, respectively, are not known.

Additionally, resistance to WSMV is also reported in maize inbred line Pa405 (McMullen et al. 1994). WSMV resistance in maize is controlled by Wsm1, Wsm2, and Wsm3 dominant genes located on chromosome 6, 3, and 10, respectively (Jones et al. 2011; McMullen et al. 1994). WSMV-resistant genes in wheat and maize were named as per the convention of naming host genes based on phenotype. However, there is no evidence to suggest that WSMV-resistant genes in wheat and maize are related.

Previously, fluorescent protein-tagged WSMV and TriMV were used to monitor virus movement in wheat and to identify viral determinants involved in cell-to-cell and long-distance movement (Tatineni et al. 2011a and b, 2014, 2015; Tatineni and French 2014). In this study, red fluorescent protein (RFP)tagged WSMV and green fluorescent protein (GFP)-tagged TriMV were used to explore the resistance mechanisms of Wsm 1 and Wsm2 genes in wheat cvs. Mace and Snowmass, respectively. At $18^{\circ} \mathrm{C}$, both WSMV and TriMV efficiently replicated and moved cell-to-cell in inoculated leaves of resistant wheat cultivars but the long-distance transport was debilitated. Additionally, the failure of long-distance movement of WSMV and TriMV in resistant wheat cultivars was found to be due to inability of these viruses to enter the vasculature. Taken together, these data suggest that Wsml and Wsm2 gene-based resistance in wheat cultivars is due to temperature-dependent impairment of viral long-distance movement with no significant effect on virus replication and cell-to-cell movement.

\section{RESULTS}

\section{Development of RFP-tagged WSMV.}

Availability of fluorescent protein-tagged viruses facilitates examination of viral resistance mechanisms of wheat cvs. Mace and Snowmass. Recently, a GFP-tagged TriMV was developed with stable and efficient expression of cycle 3 GFP (Fukuda et al. 2000) in local and systemically infected wheat leaves (Fig. 1) (Tatineni et al. 2015). Previously, the cycle 3 GFP ORF fused to a heptapeptide NIa-Pro cleavage site located between the $6 \mathrm{~K} 1 / \mathrm{CI}$ cistrons in WSMV was efficiently expressed as aggregate-like fluorescent structures, which facilitated efficient tracking of the virus in wheat (Tatineni and French 2014; Tatineni et al. 2011a, 2014). In the present study, an RFP-tagged WSMV was developed by fusing an RFP ORF (Campbell et al. 2002) to a heptapeptide cleavage site located between the 6K1/CI cistrons to obtain WSMV-RFP-6K1/CI(7aa) (Fig. 1A). The RFP is released by a cleavage of $\mathrm{P} 1$ in $c i$ at the $\mathrm{C}$-terminus of $\mathrm{P} 1$ between tyrosine and glycine residues and a cleavage at the $\mathrm{C}$-terminus of RFP in the 6K1/CI heptapeptide cleavage site by NIa-Pro in trans between glutamine and serine residues (Fig. 1A).

In vitro transcripts of WSMV-RFP-6K1/CI(7aa) (here after named as WSMV-RFP) and TriMV-GFP-NIb/CP(9aa) (renamed as TriMV-GFP) elicited infection foci on inoculated leaves of susceptible wheat $\mathrm{cv}$. Tomahawk, followed by efficient systemic infection in upper noninoculated leaves at 9 to 14 days postinoculation (dpi) (Fig. 1B). These results demonstrate that fluorescent protein-tagged WSMV and TriMV can be used to track the viruses in resistant wheat cvs. Mace and Snowmass and ascertain mechanisms of virus resistance in these cultivars.

\section{Wheat cvs. Mace and Snowmass screening for resistance against WSMV and TriMV.}

The reaction of 'Mace' and 'Snowmass' to wild-type WSMV or TriMV at $18^{\circ} \mathrm{C}$ (in a growth chamber) and $24^{\circ} \mathrm{C}$ (in a greenhouse, at $20^{\circ} \mathrm{C}$ minimum and $26^{\circ} \mathrm{C}$ maximum, with a mean temperature of $24^{\circ} \mathrm{C}$ ) was examined by inoculating wheat seedlings at the two-leaf stage, with a 1:20 dilution of crude sap 
extracted from WSMV- or TriMV-infected wheat leaves. Susceptible wheat cv. Tomahawk was included as a positive control. The upper noninoculated leaves were examined for symptom development at 14 and 21 dpi. Wheat cvs. Tomahawk and Snowmass inoculated with WSMV or TriMV elicited symptoms by $14 \mathrm{dpi}$ in $100 \%$ of plants at $24^{\circ} \mathrm{C}$ (Table 1 ). Both WSMV and TriMV caused stunting of plants and elicited severe mosaic and mottling symptoms on 'Tomahawk' and 'Snowmass' plants at $24^{\circ} \mathrm{C}$ by $21 \mathrm{dpi}$ (Fig. 2A). Additionally, WSMV induced large chlorotic stripes and yellowing of lower noninoculated leaves but TriMV did not. At $24^{\circ} \mathrm{C}$, WSMV and TriMV elicited systemic infection in 92 to $95 \%$ and $100 \%$ of wheat cv. Mace by 14 and 21 dpi, respectively (Table 1). Both WSMV and TriMV induced slight stunting of plants with chlorotic streaks and mosaic and mottling symptoms on wheat cv. Mace by 21 dpi. Also, WSMV but not TriMV induced large chlorotic stripes and yellowing of a few lower leaves by $21 \mathrm{dpi}$ (Fig. 2A). These results confirmed that wheat cvs. Mace and Snowmass are not resistant to WSMV and TriMV at the $24^{\circ} \mathrm{C}$ mean temperature present in the greenhouse.

At $18^{\circ} \mathrm{C}$, wheat $\mathrm{cv}$. Mace inoculated with WSMV or TriMV elicited systemic symptoms only in 0 to $2 \%$ of plants by 14 dpi and in 2 to $3 \%$ of plants by 21 dpi (Table 1; Fig. 2A), confirming that 'Mace' is resistant to both WSMV and TriMV at $18^{\circ} \mathrm{C}$. TriMV efficiently infected wheat cv. Snowmass in $100 \%$ of inoculated plants at $14 \mathrm{dpi}$, with moderate mosaic and mottling symptoms in upper noninoculated leaves and stunting of plants by 21 dpi (Table 1; Fig. 2A). In contrast, at $18^{\circ} \mathrm{C}$, WSMV infected only 34 and $37 \%$ of inoculated 'Snowmass' plants by 14 and $21 \mathrm{dpi}$, respectively (Table 1; Fig. 2A). Though Haley et al. (2011) reported $20 \%$ of 'Snowmass' plants were susceptible to WSMV at $18^{\circ} \mathrm{C}$, we found a slightly higher percentage (34 to

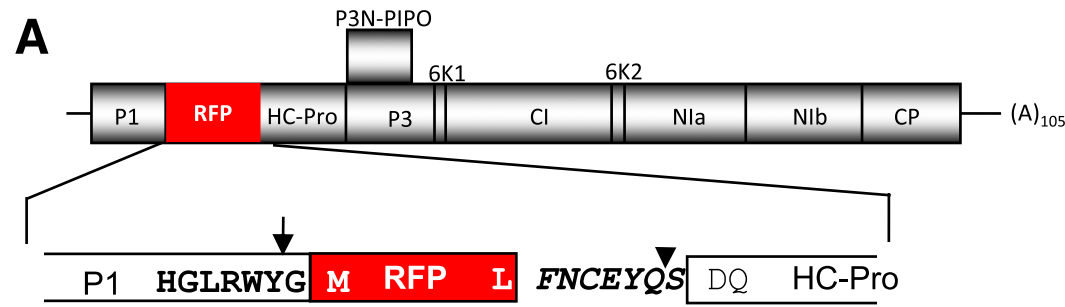
WSMV-RFP-6K1/CI(7aa)
(WSMV-RFP)

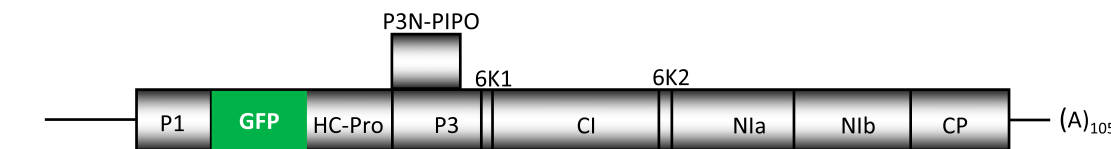

B

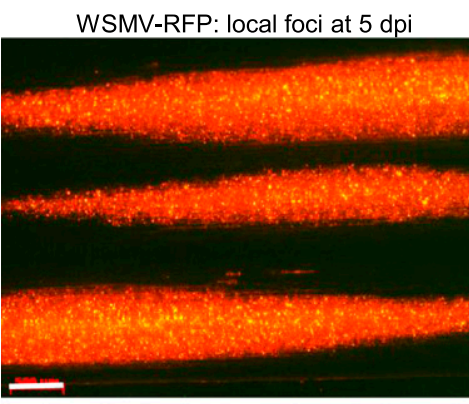

TriMV-GFP: local foci at $5 \mathrm{dpi}$

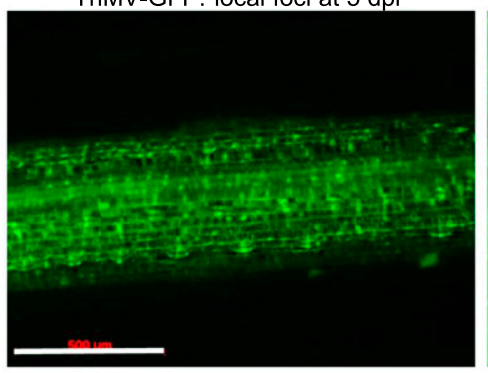

WSMV-RFP: systemic infection at $14 \mathrm{dpi}$

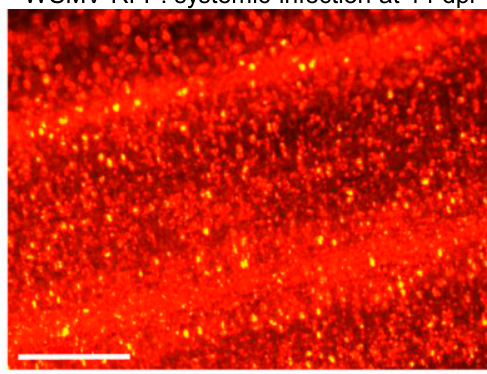

TriMV-GFP: systemic infection at $14 \mathrm{dpi}$

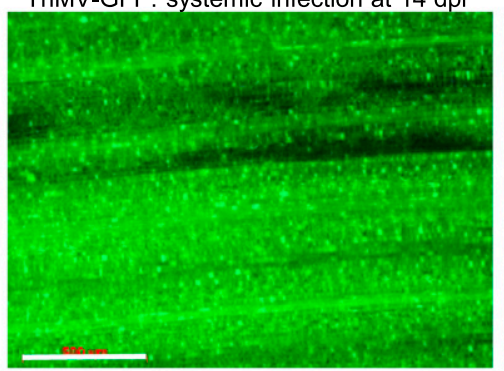

WSMV: systemic infection at $14 \mathrm{dpi}$

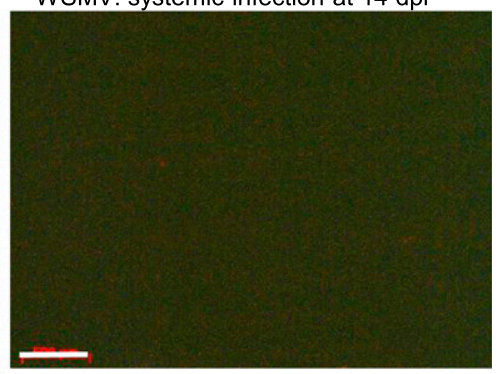

TriMV: systemic infection at $14 \mathrm{dpi}$

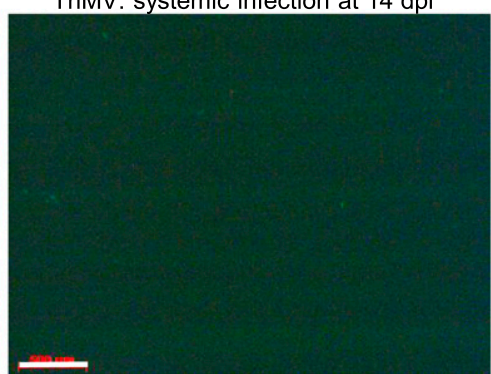

Fig. 1. Visualization of infection elicited by fluorescent protein-tagged Wheat streak mosaic virus (WSMV) and Triticum mosaic virus (TriMV). A, Schematic diagrams of genome organization of red fluorescent protein-tagged (RFP, indicated by a red rectangle) WSMV (WSMV-RFP-6K1/CI[7aa]) and green fluorescent protein-tagged(GFP, indicated by a green rectangle) Triticum mosaic virus (TriMV) (TriMV-GFP-NIb/CP[9aa]). The expanded view below the genome organization map of WSMV-RFP-6K1/CI(7aa) shows the C-terminus of the P1 cistron, followed by the RFP open reading frame fused to the NIa-Pro heptapeptide cleavage site located between 6K1/CI cistrons and the N-terminus of HC-Pro. The first and last amino acids of RFP are indicated. The locations of $\mathrm{P} 1$ cleavage in cis and NIa-Pro cleavage in trans at the engineered NIb/CP heptapeptide cleavage sites are indicated with an arrow and arrowhead, respectively. Construction and characteristic features of TriMV-GFP-NIb/CP(9aa) were described previously by Tatineni et al. (2015). For simplicity, WSMV-RFP-6K1/CI (7aa) and TriMV-GFP-NIb/CP(9aa) are renamed as WSMV-RFP and TriMV-GFP, respectively. B, Visualization of local infection foci on inoculated leaves at 5 days postinoculation (dpi) and systemic infection in upper noninoculated leaves at 14 dpi elicited by in vitro transcripts of WSMV-RFP and TriMV-GFP on wheat cv. Tomahawk. Inoculated leaves were observed under a Stereo Discovery V12 fluorescence microscope using a RFP or GFP filter. The brightness of wild-type WSMV- and TriMV-infected leaf images were adjusted to see the leaf background under RFP and GFP filters, respectively. Bars represent $500 \mu \mathrm{M}$. 
$37 \%$ ) of 'Snowmass' was susceptible to WSMV (Table 1). It is unknown if susceptible plants lack the Wsm2 gene or if this variable response is due to differential gene expression among plants of this cultivar.

To exclude the possibility of either symptomless infection, low levels of accumulation of viruses in wheat cultivars, or both, total RNA extracted from upper noninoculated leaves of wheat plants at $21 \mathrm{dpi}$ was used as the template for reverse transcription polymerase chain reaction (RT-PCR) amplification with CPspecific primers of WSMV or TriMV. Both WSMV and TriMV infected all wheat cultivars at $24^{\circ} \mathrm{C}$, as RT-PCR products were readily obtained (Fig. 2, lanes 4 to 6). No RT-PCR product was amplified from $18^{\circ} \mathrm{C}$ incubated 'Mace' plants inoculated with WSMV or TriMV (Fig. 2, lane 1). At $18^{\circ} \mathrm{C}$, RT-PCR amplification was obtained from 'Snowmass' plants inoculated with TriMV but not from WSMV-inoculated asymptomatic plants (Fig. 2, lane 2). In 'Tomahawk', RT-PCR products were obtained from WSMV or TriMV-inoculated plants at $18^{\circ} \mathrm{C}$ (Fig. 2, lane 3). These data revealed that, at $18^{\circ} \mathrm{C}$, the Wsml gene in 'Mace' confers resistance to WSMV and TriMV and Wsm2 of 'Snowmass' provides resistance to WSMV but not to TriMV.

\section{Wheat cvs. Mace and Snowmass exhibit similar levels of resistance to fluorescent protein-tagged WSMV and TriMV.}

The fluorescent protein-tagged viruses facilitate examination of the involvement of viral replication, cell-to-cell movement, long-distance transport, or a combination thereof in wheat cultivar resistance to WSMV and TriMV. It is important to know whether wheat cultivars elicit similar levels of resistance to fluorescent protein-tagged WSMV and TriMV compared with wild-type viruses. Wheat cvs. Mace, Snowmass, and Tomahawk were inoculated at the two-leaf stage with crude sap of WSMVRFP, TriMV-GFP, or both at a 1:20 dilution. The upper noninoculated leaves of wheat cultivars were examined for the presence of fluorescent foci in wheat plants inoculated with WSMV-RFP, TriMV-GFP, or both. A wheat plant was considered positive for virus infection if a single fluorescent focus was observed in upper noninoculated leaves.

At $24^{\circ} \mathrm{C}$, WSMV-RFP and TriMV-GFP efficiently infected 'Mace' and 'Snowmass' at 81 to $100 \%$ by 14 dpi and $100 \%$ by $21 \mathrm{dpi}$, similar to infections on 'Tomahawk', a susceptible wheat cultivar (Table 2). At $18^{\circ} \mathrm{C}$, WSMV-RFP and TriMVGFP infected Mace at 0 to $6 \%$ by $14 \mathrm{dpi}$ and 6 to $13 \%$ by $21 \mathrm{dpi}$ compared with $100 \%$ infection of 'Tomahawk' (Table 2). As expected, TriMV-GFP infected $100 \%$ of 'Snowmass' plants by 14 dpi and WSMV-RFP infected 22 and $28 \%$ of plants by 14 and $21 \mathrm{dpi}$, respectively (Table 2). These data suggested that 'Mace' and 'Snowmass' are similarly resistant to wild-type
(Table 1) and fluorescent protein-tagged (Table 2) viruses. Slightly increased infection rate of 'Mace' by WSMV-RFP or TriMV-GFP could be due to more stringent assay with fluorescent proteintagged viruses, as a single infection focus in upper noninoculated leaves was considered positive for virus infection.

\section{Coinoculation of wheat cvs. Mace and Snowmass with WSMV and TriMV failed}

to overcome temperature-dependent resistance.

WSMV and TriMV interact synergistically in coinfected wheat, with increased disease severity and virus concentration (Tatineni et al. 2010). Coinoculation of 'Mace' and 'Snowmass' with WSMV-RFP and TriMV-GFP was evaluated to determine whether coinfection can overcome temperaturedependent resistance of these wheat cultivars. At $18^{\circ} \mathrm{C}$, in coinoculated 'Mace', WSMV-RFP and TriMV-GFP systemically infected 0 and $4.5 \%$ of the plants by 14 dpi and $9.0 \%$ of plants, each, by $21 \mathrm{dpi}$, respectively, similar to infection by the individual viruses (Table 2). Similarly, no significant increase in 'Snowmass' infection by WSMV-RFP was observed in plants coinoculated with TriMV-GFP (Table 2). These data revealed that coinoculation of 'Mace' and 'Snowmass' with WSMV and TriMV did not alter wheat cultivar resistance.

\section{Wheat cultivar resistance to WSMV and TriMV is not at virus cell-to-cell movement.}

The above data demonstrates that expression of fluorescent proteins by WSMV or TriMV had no discernible effect on ability to infect wheat cvs. Tomahawk, Mace, or Snowmass. Hence, fluorescent protein-tagged viruses were used to explore whether resistance of 'Mace' and 'Snowmass' affects cell-tocell or long-distance movement. Cell-to-cell movement of WSMV and TriMV in wheat cvs. Mace, Snowmass, and Tomahawk was examined, using fluorescent protein-tagged viruses by measuring the extent (size of fluorescent focus) and number of foci on virus-inoculated leaves. Cell-to-cell movement of WSMV and TriMV in 'Tomahawk', a susceptible cultivar, by $5 \mathrm{dpi}$ at the nonpermissible temperature $\left(18^{\circ} \mathrm{C}\right)$ was similar to that $3 \mathrm{dpi}$ at permissible $\left(24^{\circ} \mathrm{C}\right)$ temperatures (Figs. 3, 4, and 5). This result is probably because replication of WSMV and TriMV are reduced at $18^{\circ} \mathrm{C}$. Nevertheless, WSMV-RFP and TriMV-GFP similarly elicited foci on inoculated leaves of 'Mace', 'Snowmass', and 'Tomahawk' by $5 \mathrm{dpi}$ at $18^{\circ} \mathrm{C}$ and by 3 dpi at $24^{\circ} \mathrm{C}$ (Fig. 3A to F). Additionally, coinoculation of wheat cultivars with WSMV-RFP and TriMV-GFP elicited foci similar to infection by individual viruses, except that several foci were doubly-infected with WSMV and TriMV (Fig. 3E and F). Cell-to-cell movement of WSMV and TriMV in wheat cultivars was compared within a cultivar between 18 and $24^{\circ} \mathrm{C}$

Table 1. Number of wheat plants systemically infected with wild-type Wheat streak mosaic virus (WSMV) or Triticum mosaic virus (TriMV) in a growth chamber and greenhouse

\begin{tabular}{|c|c|c|c|c|c|}
\hline \multirow[b]{2}{*}{ Wheat cultivar ${ }^{y}$} & \multirow[b]{2}{*}{ Virus } & \multicolumn{2}{|c|}{ Growth chamber $\left(18^{\circ} \mathrm{C}\right)^{\mathrm{z}}$} & \multicolumn{2}{|c|}{ Greenhouse $\left(24^{\circ} \mathrm{C}\right)^{\mathrm{z}}$} \\
\hline & & 14 dpi & 21 dpi & 14 dpi & 21 dpi \\
\hline \multirow[t]{3}{*}{ 'Mace' } & WSMV & $0 / 38(0.0 \%)$ & $1 / 38(2.6 \%)$ & $36 / 39(92 \%)$ & $39 / 39(100 \%)$ \\
\hline & TriMV & $1 / 43(2.3 \%)$ & $1 / 43(2.3 \%)$ & $36 / 38(95 \%)$ & $38 / 38(100 \%)$ \\
\hline & Buffer & $0 / 17(0.0 \%)$ & $0 / 17(0.0 \%)$ & $0 / 16(0.0 \%)$ & $0 / 16(0.0 \%)$ \\
\hline \multirow[t]{3}{*}{ 'Snowmass' } & WSMV & $12 / 35(34 \%)$ & $13 / 35(37 \%)$ & $40 / 40(100 \%)$ & $40 / 40(100 \%)$ \\
\hline & TriMV & $36 / 36(100 \%)$ & $36 / 36(100 \%)$ & $38 / 38(100 \%)$ & $38 / 38(100 \%)$ \\
\hline & Buffer & $0 / 19(0.0 \%)$ & $0 / 19(0.0 \%)$ & $0 / 18(0.0 \%)$ & $0 / 18(0.0 \%)$ \\
\hline \multirow[t]{3}{*}{ 'Tomahawk' } & WSMV & $34 / 34(100 \%)$ & $34 / 34(100 \%)$ & $34 / 34(100 \%)$ & $34 / 34(100 \%)$ \\
\hline & TriMV & $35 / 35(100 \%)$ & $35 / 35(100 \%)$ & $17 / 17(100 \%)$ & $17 / 17(100 \%)$ \\
\hline & Buffer & $0 / 17(0.0 \%)$ & $0 / 17(0.0 \%)$ & $0 / 16(0.0 \%)$ & $0 / 16(0.0 \%)$ \\
\hline
\end{tabular}

$\mathrm{y}$ Wheat seedlings at the two-leaf stage were mechanically inoculated with WSMV or TriMV at 1:20 dilution in 20 mM sodium phosphate buffer, pH 7.0. The top noninoculated leaves were visually observed for symptom development at 14 and 21 days postinoculation (dpi).

${ }^{\mathrm{z}}$ Number of plants systemically infected/number of plants mechanically inoculated, followed by $\%$ infection in parentheses. 
but not between cultivars, as the wheat cultivars evaluated are differentially susceptible to these viruses.

Number of fluorescent foci on inoculated leaves. The number of foci elicited by WSMV-RFP and TriMV-GFP on inoculated leaves of wheat cultivars was counted in 15 to 20 plants per virus per cultivar. In 'Tomahawk', WSMV and TriMV produced, respectively, 7.9 and 5.9 foci per square centimeter at $18^{\circ} \mathrm{C}$, compared with 8.3 and 4.3 foci per square centimeter at $24^{\circ} \mathrm{C}$ (Fig. 4). In coinoculated 'Tomahawk' plants, WSMV and TriMV elicited foci similarly to single-virus inoculations with 7.4 and 5.5 foci per square centimeter at $18^{\circ} \mathrm{C}$, compared with 7.5 and
4.8 foci per square centimeter at $24^{\circ} \mathrm{C}$ (Fig. 4). In 'Mace', WSMV-RFP and TriMV-GFP elicited 3.9 and 2.6 foci per square centimeter leaf at $18^{\circ} \mathrm{C}$, compared with 2.9 and 1.4 foci per square centimeter leaf at $24^{\circ} \mathrm{C}$ (Fig. 4). In coinoculated 'Mace', WSMV and TriMV elicited 5.9 and 3.4 foci per square centimeter at $18^{\circ} \mathrm{C}$, compared with 3.5 and 1.9 foci per square centimeter at $24^{\circ} \mathrm{C}$ (Fig. 4). These data suggest that WSMV and TriMV elicited similar or slightly more foci on inoculated leaves of 'Mace' at $18^{\circ} \mathrm{C}$, compared with those at $24^{\circ} \mathrm{C}$. In 'Snowmass', WSMV and TriMV elicited 6.4 and 5.9 foci per square centimeter leaf at $18^{\circ} \mathrm{C}$ and 6.6 and 5.2 foci per square centimeter at $24^{\circ} \mathrm{C}$, respectively
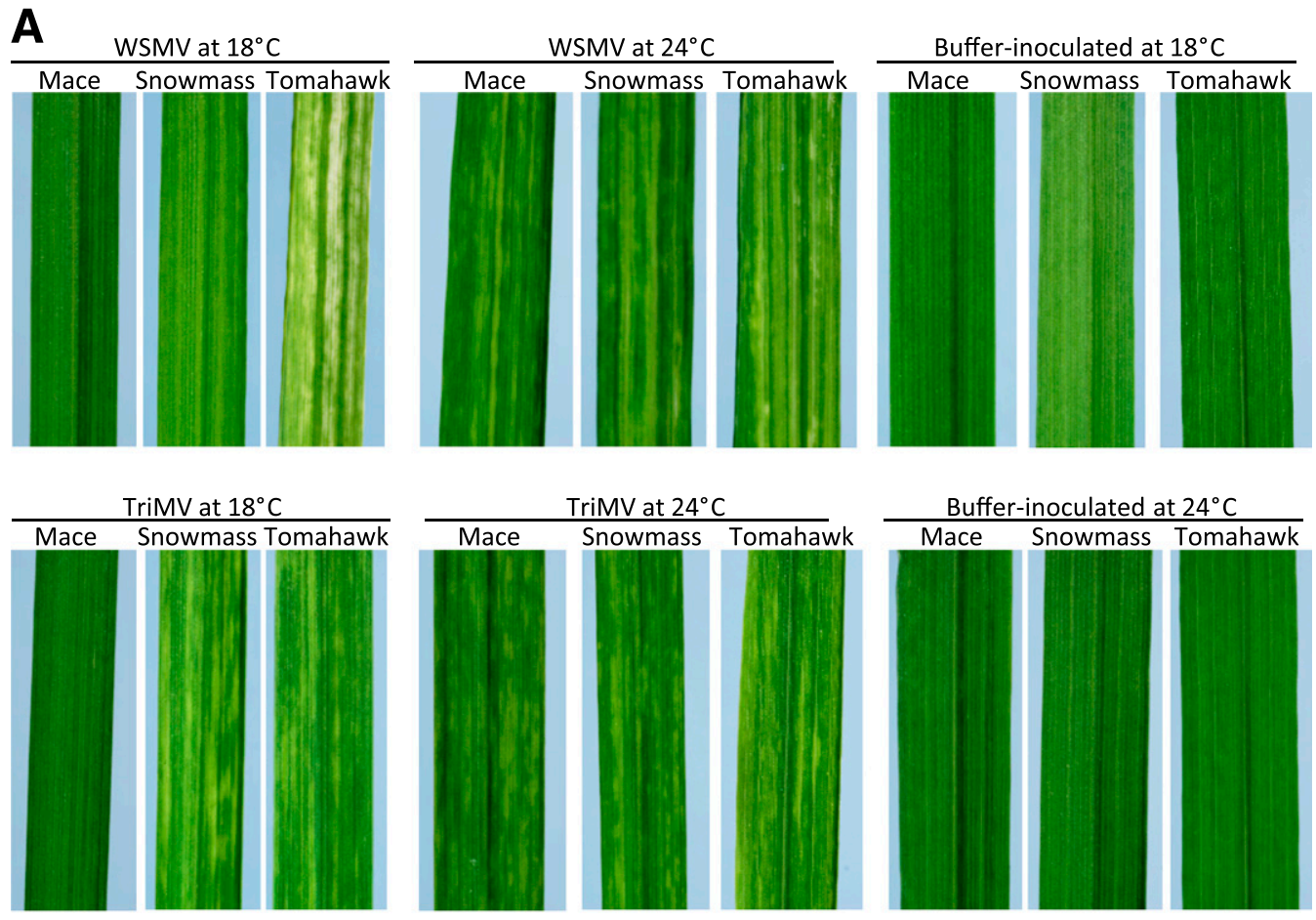

B

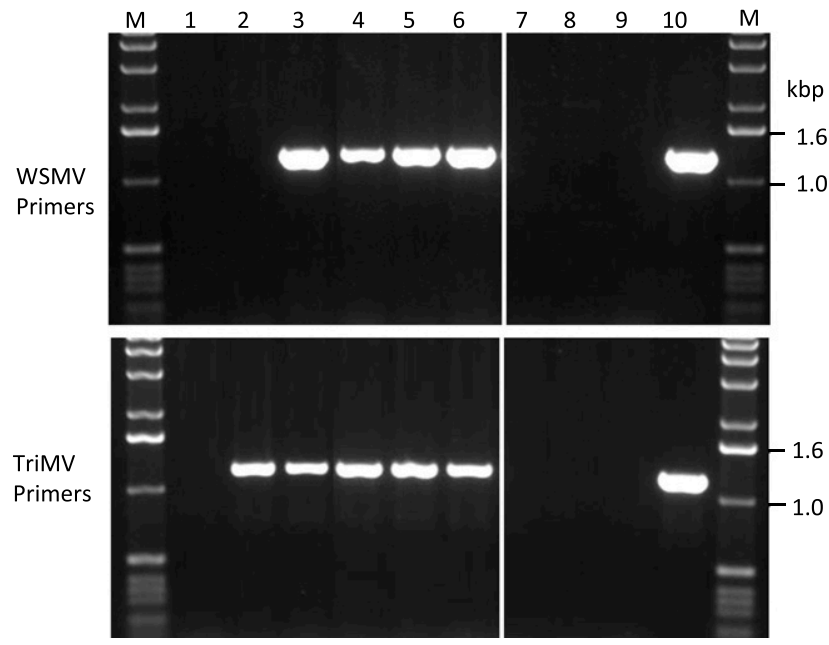

Fig. 2. Wheat cultivar screening for resistance against Wheat streak mosaic virus (WSMV) and Triticum mosaic virus (TriMV) at 18 and $24{ }^{\circ} \mathrm{C}$. A, Systemic infection of wheat cvs. Mace, Snowmass, and Tomahawk by WSMV or TriMV at 21 days postinoculation (dpi) at 18 and $24^{\circ} \mathrm{C}$. B, Reverse transcriptionpolymerase chain reaction (RT-PCR) analysis of total RNA isolated from 'Mace', 'Snowmass', and 'Tomahawk' inoculated with WSMV and TriMV at 21 dpi at 18 and $24^{\circ} \mathrm{C}$. Agarose gel electrophoresis of WSMV- and TriMV-specific RT-PCR products from wheat cultivars mechanically inoculated with wild-type WSMV or TriMV. Virus-inoculated wheat plants were maintained in a growth chamber at $18^{\circ} \mathrm{C}$ (lanes 1 to 3 ) and in the greenhouse at $24^{\circ} \mathrm{C}$ (lanes 4 to 6 ). $\mathrm{RT}$ PCR products from 'Mace' (lanes 1 and 4), 'Snowmass' (lanes 2 and 5), and 'Tomahawk' (lanes 3 and 6) were mechanically inoculated at the two-leaf stage with WSMV (top panel, lanes 1 to 6) or TriMV (bottom panel, lanes 1 to 6). Total RNA isolated from healthy 'Mace' (lane 7), 'Snowmass' (lane 8), and 'Tomahawk' (lane 9) was included as negative control. pSP6-WSMV and pTriMV-R were included as positive controls for PCR assays in lane 10 of top and bottom panels, respectively. Lane M: $1.0-\mathrm{kbp}$ DNA ladder. 
(Fig. 4), suggesting that both virulent (WSMV) and avirulent (TriMV) viruses elicited foci similarly on inoculated leaves. In coinoculated 'Snowmass' plants, WSMV and TriMV elicited, respectively, 8.9 and 6.9 foci per square centimeter at $18^{\circ} \mathrm{C}$, compared with 6.7 and 4.8 foci per square centimeter at $24^{\circ} \mathrm{C}$ (Fig. 4A and B). Collectively, these data suggested that WSMV and TriMV elicited foci on inoculated leaves of resistant 'Mace' and 'Snowmass' similarly at 18 and $24^{\circ} \mathrm{C}$. The differences in the number of foci elicited on 'Mace', 'Snowmass', and 'Tomahawk' at 18 and $24^{\circ} \mathrm{C}$ by WSMV ('Mace', $P=0.292$; 'Snowmass', $P=$ 0.855; 'Tomahawk', $P=0.684$ ) and TriMV ('Mace', $P=0.191$; 'Snowmass', $P=0.721$; 'Tomahawk', $P=0.227$ ) were not statistically significant.

Size of fluorescent foci on inoculated leaves. Though WSMV and TriMV elicited foci on inoculated leaves of resistant wheat cultivars similarly at permissible and nonpermissible temperatures, it is possible that resistance to virus infection might have affected foci size. The size of foci elicited by WSMV-RFP and TriMV-GFP on inoculated leaves of wheat cultivars was measured from 20 foci per virus per cultivar. In 'Tomahawk', WSMV and TriMV elicited $0.94-$ and $0.60-\mathrm{mm}^{2}$ foci at $18^{\circ} \mathrm{C}$, compared with 0.86 - and $0.75-\mathrm{mm}^{2}$ foci at $24^{\circ} \mathrm{C}$ (Fig. 5). In coinoculated 'Tomahawk', WSMV and TriMV produced 0.91and $0.56-\mathrm{mm}^{2}$ foci at $18^{\circ} \mathrm{C}$, compared with 0.80 - and $0.66-\mathrm{mm}^{2}$ foci at $24^{\circ} \mathrm{C}$, suggesting that, by $5 \mathrm{dpi}$, foci sizes at nonpermissible temperature are comparable to those at permissible temperatures by 3 dpi. In 'Mace', WSMV and TriMV elicited 0.89 - and $0.57-\mathrm{mm}^{2}$ foci at $18^{\circ} \mathrm{C}$, compared with 0.73 - and $0.58-\mathrm{mm}^{2}$ foci at $24^{\circ} \mathrm{C}$ (Fig. 5). In coinoculated 'Mace', WSMV and TriMV produced, respectively, $0.74-$ and $0.53-\mathrm{mm}^{2}$ foci at $18^{\circ} \mathrm{C}$, compared with $0.73-$ and $0.56-\mathrm{mm}^{2}$ foci at $24^{\circ} \mathrm{C}$ (Fig. 5). In 'Snowmass', WSMV and TriMV elicited 1.35- and $0.86-\mathrm{mm}^{2}$ foci at $18^{\circ} \mathrm{C}$, compared with 0.90 - and $0.75-\mathrm{mm}^{2}$ foci at $24^{\circ} \mathrm{C}$ (Fig. 5). In coinoculated 'Snowmass', WSMV and TriMV produced foci similar to those in single-virus inoculations. These data indicated that, in resistant wheat cultivars, WSMV and TriMV formed foci with approximately similar sizes at 18 and $24^{\circ} \mathrm{C}$. The differences in foci sizes at 18 and $24^{\circ} \mathrm{C}$ elicited by WSMV ('Mace', $P=0.518$; 'Snowmass', $P=$ 0.613; 'Tomahawk', $P=0.527$ ) and TriMV ('Mace', $P=0.705$; 'Snowmass', $P=0.494$; 'Tomahawk', $P=0.380$ ) in resistant and susceptible wheat cultivars were not statistically significant.
Taken together, the number and size of foci elicited by WSMV and TriMV on inoculated leaves of wheat cvs. Mace, Snowmass, and Tomahawk at $18^{\circ} \mathrm{C}$ are comparable to those at $24^{\circ} \mathrm{C}$, suggesting that 'Mace' and 'Snowmass' resistance at $18^{\circ} \mathrm{C}$ does not affect local virus cell-to-cell movement.

\section{WSMV and TriMV efficiently replicated in inoculated leaves of resistant wheat cultivars.}

We next examined whether cell-to-cell movement of WSMV and TriMV in resistant cultivars resulted from efficient virus replication. Total RNA, extracted at 5 and 3 dpi from virusinoculated leaves of wheat plants incubated at 18 and $24^{\circ} \mathrm{C}$, respectively, was used for absolute quantification of WSMV and TriMV genomic RNAs as described (Tatineni et al. 2010). The number of genomic RNA copies of WSMV and TriMV in singleor double-virus inoculated leaves of 'Mace', 'Snowmass', and 'Tomahawk' at 18 and $24^{\circ} \mathrm{C}$ is presented in Table 3. In all wheat cultivars inoculated with individual viruses at $18^{\circ} \mathrm{C}$, genomic RNA of TriMV accumulated at enhanced levels while WSMV accumulated at reduced levels, compared with those at $24^{\circ} \mathrm{C}$ (Table 3). The lower accumulation of WSMV genomic RNA in resistant as well as susceptible wheat cultivars at $18^{\circ} \mathrm{C}$, suggests that WSMV might replicate at reduced levels at $18^{\circ} \mathrm{C}$. In coinoculated (WSMV+TriMV) wheat leaves, both WSMV and TriMV genomic RNAs accumulated at higher levels at $18^{\circ} \mathrm{C}$, compared with those at $24^{\circ} \mathrm{C}$ in all cultivars (Table 3). The increased levels of WSMV accumulation in coinoculated plants compared with single-virus inoculations could be due to synergistic interaction between WSMV and TriMV (Tatineni et al. 2010). Collectively, these data suggest that WSMV and TriMV replicated efficiently in inoculated leaves of resistant and susceptible wheat. Differences in accumulation of genomic RNAs of WSMV ('Mace', $P=0.066$; 'Tomahawk', $P=0.952$ ) and TriMV ('Snowmass', $P=0.090$; 'Tomahawk', $P=0.150$ ) in resistant and susceptible wheat cultivars at 18 and $24^{\circ} \mathrm{C}$ were not statistically significant but were significantly different in 'Snowmass' for WSMV $(0.0007)$ and in 'Mace' for TriMV $(P=0.006)$.

\section{WSMV and TriMV exhibit cultivar-specific} and temperature-dependent long-distance movement.

Wheat cvs. Mace, Snowmass, and Tomahawk were inoculated with crude sap of WSMV-RFP or TriMV-GFP at the

Table 2. Number of wheat plants systemically infected with red fluorescent protein-tagged Wheat streak mosaic virus (WSMV-RFP) and green fluorescent protein-tagged Triticum mosaic virus (TriMV-GFP) at 18 and $24^{\circ} \mathrm{C}$

\begin{tabular}{|c|c|c|c|c|c|}
\hline \multirow[b]{2}{*}{ Cultivar $^{y}$} & \multirow[b]{2}{*}{ Virus } & \multicolumn{2}{|c|}{ Growth chamber $\left(18^{\circ} \mathrm{C}\right)^{\mathrm{z}}$} & \multicolumn{2}{|c|}{ Greenhouse $\left(24^{\circ} \mathrm{C}\right)^{\mathrm{z}}$} \\
\hline & & 14 dpi & 21 dpi & 14 dpi & 21 dpi \\
\hline \multirow[t]{5}{*}{ 'Mace' } & WSMV-RFP & $0 / 17(0.0 \%)$ & $1 / 17(5.9 \%)$ & $17 / 21(81 \%)$ & $21 / 21(100 \%)$ \\
\hline & TriMV-GFP & $1 / 16(6.0 \%)$ & $2 / 16(13 \%)$ & $22 / 22(100 \%)$ & $22 / 22(100 \%)$ \\
\hline & DI: WSMV-RFP & $0 / 22(0.0 \%)$ & $2 / 22(9.0 \%)$ & $17 / 18(94 \%)$ & $18 / 18(100 \%)$ \\
\hline & DI: TriMV-GFP & $1 / 22(4.5 \%)$ & $2 / 22(9.0 \%)$ & $16 / 17(94 \%)$ & $17 / 17(100 \%)$ \\
\hline & Buffer & $0 / 14(0.0 \%)$ & $0 / 14(0.0 \%)$ & $0 / 16(0.0 \%)$ & $0 / 16(0.0 \%)$ \\
\hline \multirow[t]{5}{*}{ 'Snowmass' } & WSMV-RFP & $4 / 18(22 \%)$ & $5 / 18(28 \%)$ & $17 / 17(100 \%)$ & $17 / 17(100 \%)$ \\
\hline & TriMV-GFP & $17 / 17(100 \%)$ & $17 / 17(100 \%)$ & $17 / 17(100 \%)$ & $17 / 17(100 \%)$ \\
\hline & DI: WSMV-RFP & $4 / 19(21 \%)$ & $6 / 19(32 \%)$ & $18 / 18(100 \%)$ & $18 / 18(100 \%)$ \\
\hline & DI: TriMV-GFP & $16 / 17(94 \%)$ & $16 / 17(94 \%)$ & $18 / 18(100 \%)$ & $18 / 18(100 \%)$ \\
\hline & Buffer & $0 / 17(0.0 \%)$ & $0 / 17(0.0 \%)$ & $0 / 16(0.0 \%)$ & $0 / 16(0.0 \%)$ \\
\hline \multirow[t]{5}{*}{ 'Tomahawk' } & WSMV-RFP & $16 / 16(100 \%)$ & $16 / 16(100 \%)$ & $17 / 17(100 \%)$ & $17 / 17(100 \%)$ \\
\hline & TriMV-GFP & $20 / 20(100 \%)$ & $20 / 20(100 \%)$ & $19 / 19(100 \%)$ & $19 / 19(100 \%)$ \\
\hline & DI: WSMV-RFP & $19 / 19(100 \%)$ & $19 / 19(100 \%)$ & $14 / 14(100 \%)$ & $14 / 14(100 \%)$ \\
\hline & DI: TriMV-GFP & $19 / 19(100 \%)$ & $19 / 19(100 \%)$ & $14 / 14(100 \%)$ & $14 / 14(100 \%)$ \\
\hline & Buffer & $0 / 15(0.0 \%)$ & $0 / 15(0.0 \%)$ & $0 / 17(0.0 \%)$ & $0 / 17(0.0 \%)$ \\
\hline
\end{tabular}

y Wheat seedlings at the two-leaf stage were mechanically inoculated with WSMV-RFP, TriMV-GFP, or WSMV-RFP+TriMV-GFP at 1:20 dilution in 10 mM sodium phosphate buffer, $\mathrm{pH}$ 7.0. Two upper noninoculated leaves per plant were observed for fluorescent protein under a Stereo Discovery V12 fluorescence microscope. The presence of at least a single fluorescent focus was considered as positive for infection.

${ }^{\mathrm{z}}$ Number of plants systemically infected/number of plants mechanically inoculated, followed by \% infection in parentheses. DI: double inoculation with WSMV-RFP+TriMV-GFP; dpi: days postinoculation. 
two-leaf stage to track viral long-distance movement by observing fluorescent protein in upper noninoculated leaves. By $21 \mathrm{dpi}$, both WSMV and TriMV moved long distance at $24^{\circ} \mathrm{C}$ in all wheat cultivars, as fluorescent proteins were readily observed in $100 \%$ of inoculated plants (Fig. 6C and D). However, fluorescent proteins were not observed in upper noninoculated leaves of WSMV-RFP- or TriMV-GFP-inoculated 'Mace' at $18^{\circ} \mathrm{C}$ (Fig. 6A and B) but developed local (fluorescent) foci on $100 \%$ of inoculated leaves (Fig. 3A and B), suggesting that WSMV and TriMV failed to move long distance in 'Mace' at $18^{\circ} \mathrm{C}$. TriMV-GFP moved long distance in 'Snowmass' at $18^{\circ} \mathrm{C}$, as fluorescent protein was observed in upper noninoculated leaves while RFP was observed in only $28 \%$ of upper noninoculated leaves of plants inoculated with WSMV-RFP, which is in agreement with approximately $20 \%$ susceptibility of 'Snowmass' to WSMV (Fig. 6A and B; Table 2) (Haley et al. 2011). Coinoculation (WSMV-RFP+TriMV-GFP) of 'Tomahawk', 'Snowmass', and 'Mace' plants resulted in efficient systemic coinfection by both viruses at $24^{\circ} \mathrm{C}$ and, in 'Tomahawk', at $18^{\circ} \mathrm{C}$ by $21 \mathrm{dpi}$ (Fig. $6 \mathrm{E}$ and F). As expected, neither virus infected wheat cv. Mace systemically in coinoculated plants at $18^{\circ} \mathrm{C}$ (Fig. 6F). However, coinoculation of 'Snowmass' at $18^{\circ} \mathrm{C}$ resulted in systemic infection by TriMV-GFP, but only approximately $30 \%$ of plants were doubly-infected with WSMV-GFP and TriMV-GFP (Fig. 6F; Table 2).

Development of local foci by WSMV-RFP in all inoculated 'Snowmass' leaves at $18^{\circ} \mathrm{C}$ together with failure to infect approximately $70 \%$ of plants systemically suggest that WSMV failed to move long distance in most 'Snowmass' plants. These data revealed that both viruses moved long distance in all wheat cultivars at $24^{\circ} \mathrm{C}$ and only cell-to-cell but not long distance at $18^{\circ} \mathrm{C}$ in resistant cultivars, suggesting that WSMV and TriMV exhibit cultivar-specific and temperature-dependent long-distance movement.

\section{WSMV and TriMV failed to enter the vasculature of resistant wheat cultivars at $18^{\circ} \mathrm{C}$.}

Plant viruses fail to move long distance, possibly due to inability to one or both enter or exit the vasculature at a distal place for the subsequent spread by cell-to-cell movement.
A

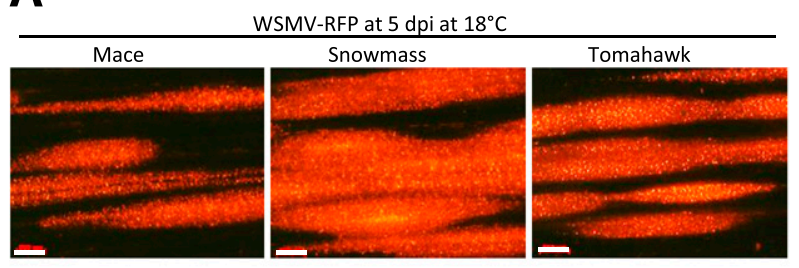

C

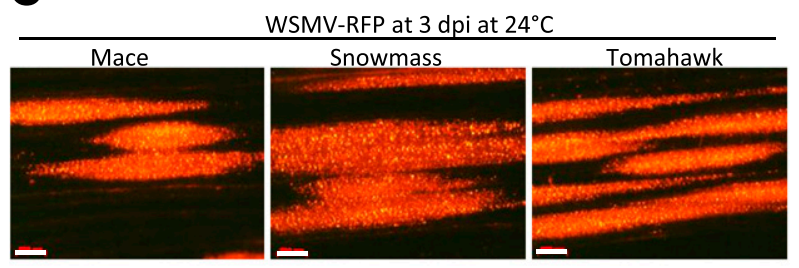

$\mathbf{E}$

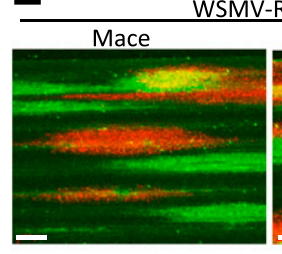

WSMV-RFP+TriMV-GFP at 3 dpi at $24^{\circ} \mathrm{C}$
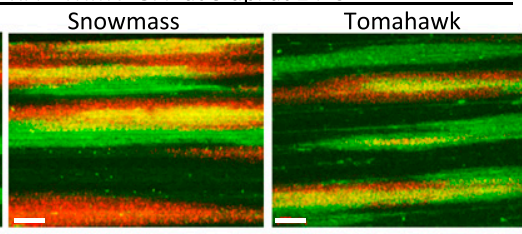

$\mathbf{G}$
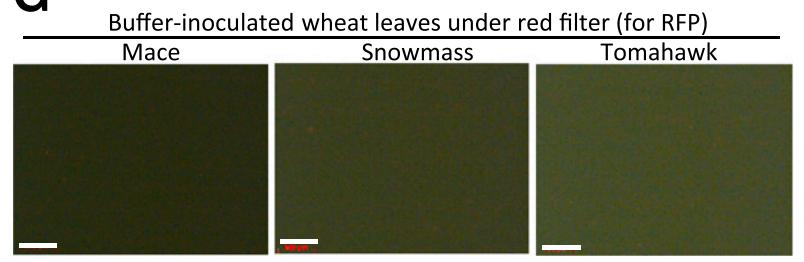

$\mathbf{H}$

B

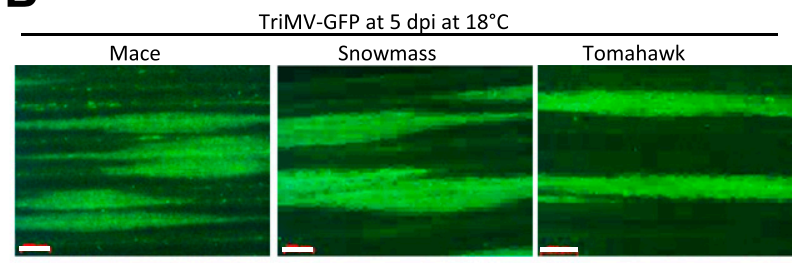

D

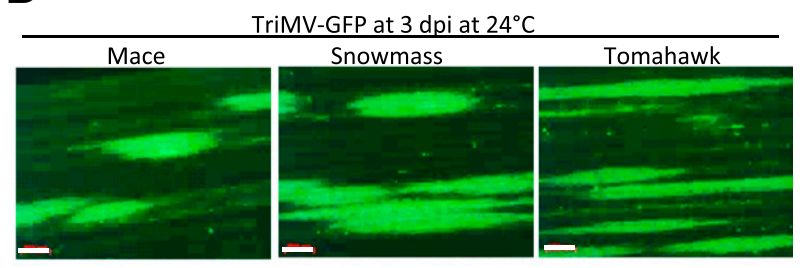

$\mathbf{F}$
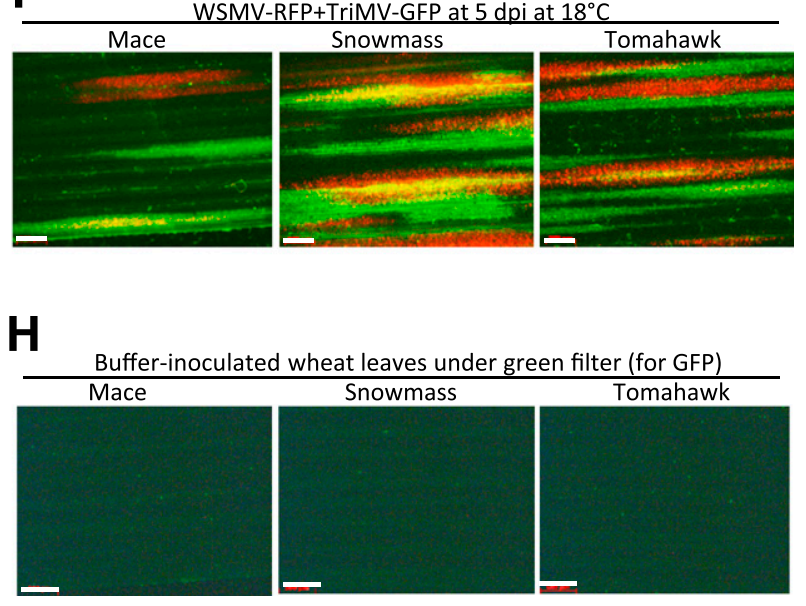

Fig. 3. Wheat streak mosaic virus (WSMV) and Triticum mosaic virus (TriMV) facilitated efficient cell-to-cell movement in resistant wheat cultivars at $18^{\circ} \mathrm{C}$. A and $\mathbf{C}$, Local foci elicited by WSMV-RFP (red fluorescent protein), B and D, TriMV-GFP (green fluorescent protein), and $\mathbf{E}$ and $\mathbf{F}$, WSMV-RFP+TriMV-GFP at $18^{\circ} \mathrm{C}(\mathrm{A}, \mathrm{B}$, and $\mathrm{F})$ and $24^{\circ} \mathrm{C}(\mathrm{C}, \mathrm{D}$, and $\mathrm{E})$ in inoculated wheat leaves. Note that WSMV-RFP and TriMV-GFP facilitated efficient cell-to-cell movement in inoculated leaves of 'Mace' and 'Snowmass' at $18^{\circ} \mathrm{C}$ (A and B). As a control, susceptible wheat cv. Tomahawk' was included as a positive control for cell-tocell movement of WSMV-RFP and TriMV-GFP. G, Buffer-inoculated wheat leaves were observed under RFP or $\mathbf{H}$, GFP filters as negative controls. Inoculated wheat leaves were observed under a Stereo Discovery V12 fluorescence microscope using RFP or GFP filters. Merged images of RFP and GFP from mixed inoculation were presented in E and F. Note that colocalization of RFP and GFP foci resulted in a yellow color in mixed inoculations. The brightness of bufferinoculated images in $\mathrm{G}$ and $\mathrm{H}$ were adjusted to see the background of objects under RFP and GFP narrow-band filters, respectively. Bars represent $500 \mu \mathrm{M}$. 
Reasons for lack of long-distance movement of WSMV and TriMV in resistant wheat cultivars at $18^{\circ} \mathrm{C}$ were examined by inoculating resistant cultivars Mace and Snowmass and susceptible cultivar Tomahawk with WSMV-RFP or TriMV-GFP. The inoculated leaves and leaf sheaths and crowns from plants incubated at $18^{\circ} \mathrm{C}$ were observed at $21 \mathrm{dpi}$, for the presence of fluorescent proteins (Fig. 7A). Local foci spread from initial infection sites throughout most of the inoculated leaves, further confirming efficient cell-to-cell movement of WSMV and TriMV in resistant and susceptible wheat cultivars alike (Fig. 7B). In 'Tomahawk', fluorescent proteins were readily detected in WSMV-RFP- or TriMV-GFP-inoculated leaf sheaths (Fig. 7C). In contrast, no fluorescent proteins were detected in leaf sheaths of WSMV-RFP- or TriMV-GFP-inoculated leaves of 'Mace' (Fig. 7C). Since approximately $20 \%$ of 'Snowmass' plants were susceptible to WSMV systemic infection (Haley et al. 2011), leaf sheaths of 'Snowmass' plants that WSMVRFP failed to systemically infect (but had local foci) were examined for the presence of RFP in leaf sheaths. No RFP was detected in leaf sheaths of WSMV-RFP-inoculated leaves of 'Snowmass' that contained local foci (Fig. 7C). In contrast, fluorescent protein was readily detected in leaf sheaths of TriMV-GFP-inoculated 'Snowmass' plants (Fig. 7C). These data revealed that WSMV and TriMV efficiently moved cell to cell from initial infection foci in resistant wheat cultivars at $18^{\circ} \mathrm{C}$ but failed to enter the vasculature of leaf sheaths to establish a successful systemic infection. At $24^{\circ} \mathrm{C}$, fluorescent proteins were readily detected at $21 \mathrm{dpi}$ in the leaf sheaths of 'Mace', 'Snowmass', and 'Tomahawk' plants inoculated with WSMV-RFP or TriMV-GFP (data not shown).

The crowns of wheat plants inoculated with WSMV-RFP or TriMV-GFP were examined for the presence of fluorescent proteins as both WSMV and TriMV must infect the crown before moving systemically. The crowns of 'Mace' inoculated with WSMV-RFP or TriMV-GFP were free from fluorescent proteins (Fig. 7D), suggesting that WSMV and TriMV failed to move into crowns at detectable levels. Similarly, the crowns of 'Snowmass' that WSMV-RFP failed to infect systemically but elicited local foci were also free from detectable levels of RFP (Fig. 7D). In contrast, fluorescent proteins were readily detected in the crowns of 'Tomahawk' inoculated with WSMVRFP or TriMV-GFP, which is consistent with 'Tomahawk's susceptibility to WSMV and TriMV. These data suggest that WSMV and TriMV are unable to reach the crowns of resistant wheat cultivars at $18^{\circ} \mathrm{C}$.

To exclude the possibility that WSMV or TriMV might be present in the crowns at levels undetectable by fluorescence assays, total RNA extracted from three crowns per sample was

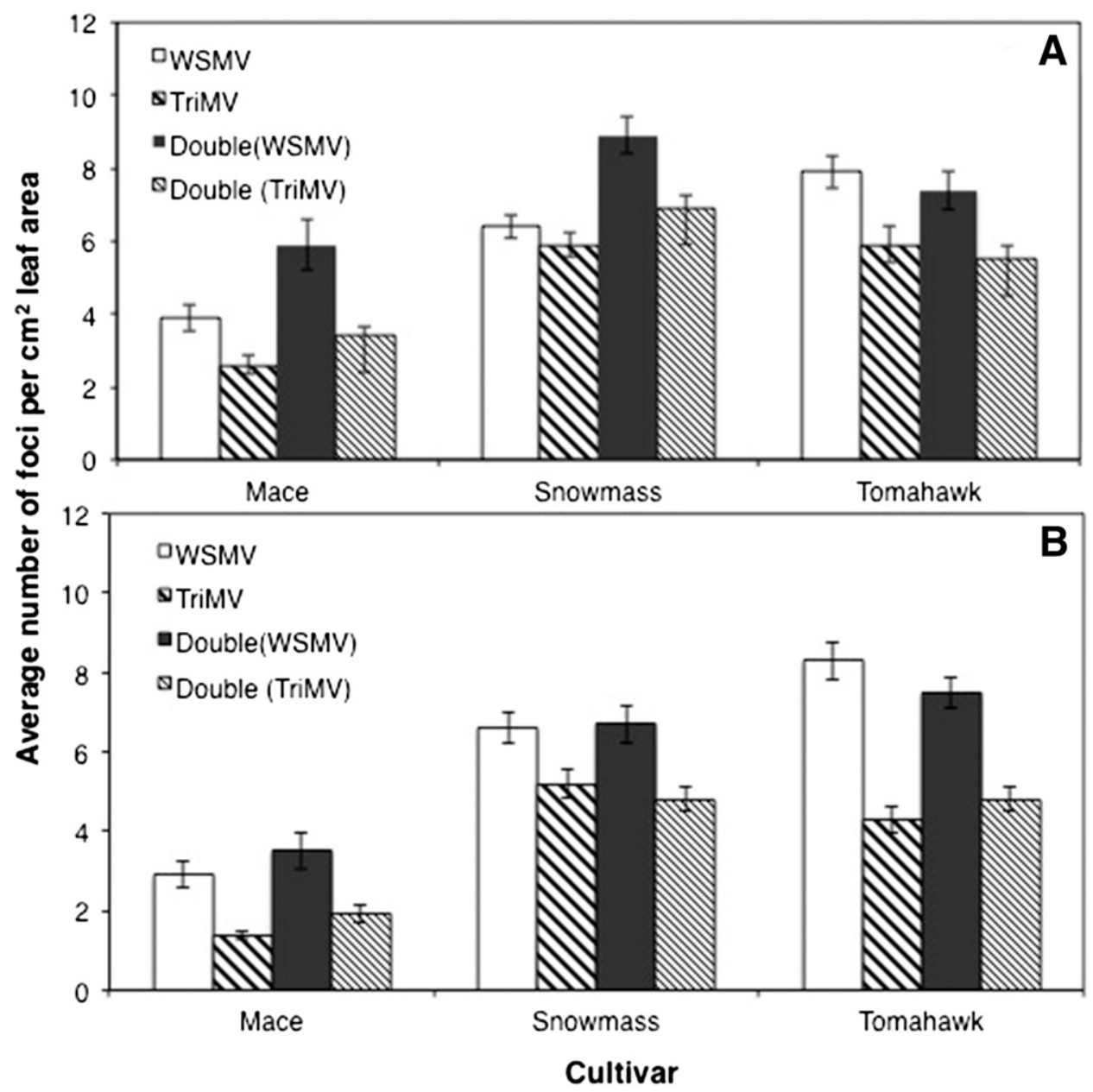

Fig. 4. A, The average number of virus infection foci per square centimeter of leaf area (mean \pm standard error) in inoculated leaves of wheat cvs. Mace, Snowmass, and Tomahawk at $18^{\circ} \mathrm{C}$ at 5 days postinoculation (dpi) and $\mathbf{B}$, at $24^{\circ} \mathrm{C}$ at 3 dpi. Vertical bars represent standard error. Wheat seedlings were inoculated with crude sap of either red fluorescent protein-tagged Wheat streak mosaic virus (WSMV-RFP), green fluorescent protein-tagged Triticum mosaic virus (TriMV-GFP), or both, at a 1:20 dilution in $20 \mathrm{mM}$ sodium phosphate buffer, $\mathrm{pH} 7.0$, and plants were maintained at 18 or $24^{\circ} \mathrm{C}$. Double: coinoculation with WSMV-RFP and TriMV-GFP. The differences in the number of foci elicited on 'Mace', 'Snowmass', and 'Tomahawk' at 18 and $24{ }^{\circ} \mathrm{C}$ by WSMV $(P=$ $0.292, P=0.855$, and $P=0.684$, respectively) and TriMV $(P=0.191, P=0.721$, and $P=0.227$, respectively $)$ were not statistically significant. 
used as a template for RT-PCR using CP-specific primers of WSMV (Fig. 7F, top panel) and TriMV (Fig. 7F, bottom panel). No RT-PCR product was obtained from 'Mace' crowns inoculated with one or both WSMV or TriMV (Fig. 7F, lanes 1 to 3). In 'Snowmass', as expected, RT-PCR amplification was obtained from TriMV-GFP-inoculated plants but not from WSMV-RFPinoculated plants (Fig. 7F, lanes 4 to 6). In 'Tomahawk', RT-PCR product was obtained from plants inoculated with one or both WSMV or TriMV (Fig. 7F, lanes 7 to 9). Taken together, these data demonstrate that WSMV and TriMV failed to move long

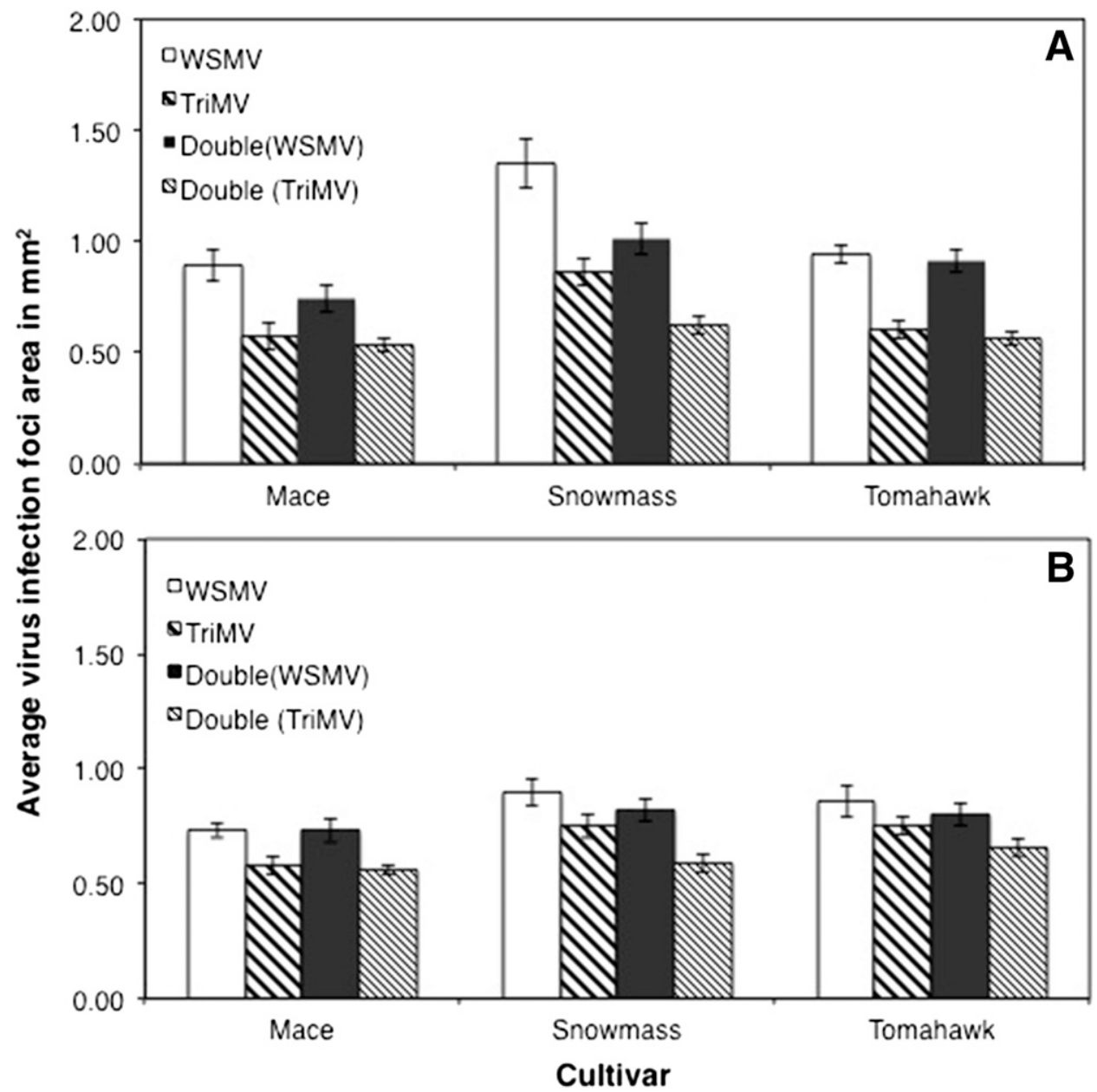

Fig. 5. A, The average size of virus infection foci in square millimeters (mean \pm standard error) in inoculated leaves of 'Mace', 'Snowmass', and 'Tomahawk' at $18^{\circ} \mathrm{C}$ at 5 days postinoculation (dpi) and $\mathbf{B}$, at $24^{\circ} \mathrm{C}$ at $3 \mathrm{dpi}$. Vertical bars represent standard error. Wheat seedlings were inoculated with crude sap of either red fluorescent protein-tagged Wheat streak mosaic virus (WSMV-RFP), green fluorescent protein-tagged Triticum mosaic virus (TriMV-GFP), or both, at 1:20 dilution in sodium phosphate buffer, $\mathrm{pH} 7.0$, and were incubated at 18 or $24^{\circ} \mathrm{C}$. Double: coinoculation with WSMV-RFP and TriMV-GFP. The differences in foci sizes at 18 and $24^{\circ} \mathrm{C}$ elicited elicited on 'Mace', 'Snowmass', and 'Tomahawk' by WSMV $(P=0.518, P=0.613$, and $P=0.527$, respectively $)$ and TriMV ( $P=0.705, P=0.494$, and $P=0.380$, respectively) in resistant and susceptible wheat cultivars were not statistically significant.

Table 3. Absolute quantification of Wheat streak mosaic virus (WSMV) and Triticum mosaic virus (TriMV) genomic RNAs in inoculated leaves of three wheat cultivars held at 18 and $24^{\circ} \mathrm{C}$

\begin{tabular}{|c|c|c|c|c|}
\hline \multirow[b]{2}{*}{ Virus $^{\mathbf{y}}$} & \multirow[b]{2}{*}{ Degrees } & \multicolumn{3}{|c|}{ Number of genomic RNA copies in wheat cultivars ${ }^{\mathrm{Z}}$} \\
\hline & & 'Mace' & 'Snowmass' & 'Tomahawk' \\
\hline \multirow[t]{2}{*}{ WSMV-RFP } & $18^{\circ} \mathrm{C}$ & $1.43 \times 10^{4} \pm 4.91 \times 10^{3} \mathrm{a}$ & $3.64 \times 10^{4} \pm 5.21 \times 10^{2} \mathrm{~b}$ & $3.25 \times 10^{4} \pm 4.90 \times 10^{3} \mathrm{a}$ \\
\hline & $24^{\circ} \mathrm{C}$ & $4.35 \times 10^{4} \pm 1.19 \times 10^{4} \mathrm{a}$ & $1.50 \times 10^{5} \pm 2.30 \times 10^{4} \mathrm{a}$ & $5.50 \times 10^{4} \pm 1.17 \times 10^{4} \mathrm{a}$ \\
\hline \multirow[t]{2}{*}{ TriMV-GFP } & $18^{\circ} \mathrm{C}$ & $1.53 \times 10^{4} \pm 2.36 \times 10^{3} \mathrm{a}$ & $5.35 \times 10^{4} \pm 7.97 \times 10^{3} \mathrm{a}$ & $6.38 \times 10^{4} \pm 3.74 \times 10^{3} a$ \\
\hline & $24^{\circ} \mathrm{C}$ & $3.40 \times 10^{3} \pm 9.10 \times 10^{2} b$ & $2.48 \times 10^{4} \pm 9.67 \times 10^{3} \mathrm{a}$ & $1.60 \times 10^{4} \pm 7.97 \times 10^{3} \mathrm{a}$ \\
\hline \multirow[t]{2}{*}{ DI: WSMV-RFP } & $18^{\circ} \mathrm{C}$ & $5.20 \times 10^{4} \pm 1.75 \times 10^{3} \mathrm{a}$ & $1.35 \times 10^{5} \pm 2.14 \times 10^{4} \mathrm{a}$ & $7.74 \times 10^{4} \pm 1.85 \times 10^{4} \mathrm{a}$ \\
\hline & $24^{\circ} \mathrm{C}$ & $2.58 \times 10^{4} \pm 8.50 \times 10^{3} \mathrm{a}$ & $9.10 \times 10^{4} \pm 3.13 \times 10^{4} \mathrm{a}$ & $4.68 \times 10^{4} \pm 9.96 \times 10^{3} a$ \\
\hline \multirow[t]{2}{*}{ DI: TriMV-GFP } & $18^{\circ} \mathrm{C}$ & $1.39 \times 10^{4} \pm 5.16 \times 10^{3} \mathrm{a}$ & $4.38 \times 10^{4} \pm 5.34 \times 10^{3} \mathrm{a}$ & $2.08 \times 10^{4} \pm 2.78 \times 10^{3} a$ \\
\hline & $24^{\circ} \mathrm{C}$ & $8.54 \times 10^{3} \pm 2.69 \times 10^{3} \mathrm{a}$ & $2.59 \times 10^{4} \pm 6.91 \times 10^{3} \mathrm{a}$ & $1.26 \times 10^{4} \pm 2.13 \times 10^{3} \mathrm{a}$ \\
\hline
\end{tabular}


distance in resistant wheat cultivars, as these viruses failed to enter the vasculature of resistant wheat at $18^{\circ} \mathrm{C}$.

\section{DISCUSSION}

In this study, we found that temperature-dependent impairment of viral long-distance transport explains resistance in wheat cv. Mace against WSMV and TriMV and cv. Snowmass against WSMV at $18^{\circ} \mathrm{C}$. WSMV and TriMV replicated and moved cell to cell efficiently in inoculated leaves but failed to establish systemic infection, as both viruses did not enter the vasculature of resistant wheat cultivars at $18^{\circ} \mathrm{C}$. Thus, wheat cvs. Mace and Snowmass provide resistance by blocking viruses from entering the vasculature, thereby precluding long-distance movement without significant effects on virus replication and local cell-to-cell movement.

The molecular basis for genetic resistance to viruses in cereal hosts is poorly understood (Kang et al. 2005a). The fluorescent protein-tagged WSMV and TriMV facilitated examination of the mechanisms of Wsm1- and Wsm2-conferred resistance in wheat cvs. Mace and Snowmass, respectively. Both WSMV and TriMV replicated and moved cell to cell in inoculated leaves of resistant and susceptible wheat cultivars similarly at permissible and nonpermissible temperatures. The difference in replication and cell-to-cell movement of WSMV and TriMV between $5 \mathrm{dpi}$ at $18^{\circ} \mathrm{C}$ and 3 dpi at $24^{\circ} \mathrm{C}$ was similar in both susceptible and resistant wheat cultivars. These data suggest that WSMV and TriMV replicate and facilitate cell-to-cell movement similarly in resistant and susceptible cultivars at $18^{\circ} \mathrm{C}$. However, at $18^{\circ} \mathrm{C}$, both WSMV and TriMV failed to move long distance in wheat cv. Mace; also TriMV moved long distance in 'Snowmass' but WSMV did not. The debilitated long-distance movement of WSMV and TriMV in resistant wheat cultivars at $18^{\circ} \mathrm{C}$ is due to blocked virus entry into the vasculature. These data revealed that resistance in 'Mace' and 'Snowmass' is not at viral replication and local cell-to-cell movement steps of the virus life cycle but is due to temperaturedependent impairment of viral long-distance transport.

Many host $R$ genes against members of family Potyviridae are recessive alleles of genes encoding translation initiation factors such as eIF4E and its isoforms (Kang et al. 2005a; Mazier et al. 2011; Ruffel et al. 2002; Wang and Krishnaswamy 2012; Yeam et al. 2007). Recessive resistance, in most cases, results in an undetectable level of virus multiplication in inoculated leaves, as shown for $p v r 2$ in pepper against TEV and Pepper vein mottle virus (Kang et al. 2005b; Ruffel et al. 2006), mol in lettuce against Lettuce mosaic virus (Nicaise et al. 2003), pot-1 in tomato
A

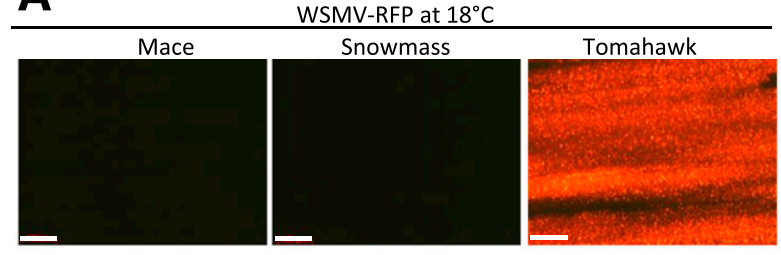

C

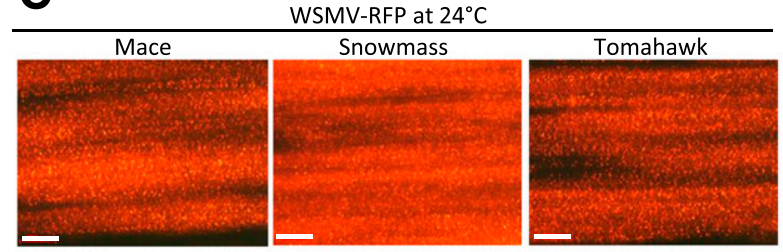

E

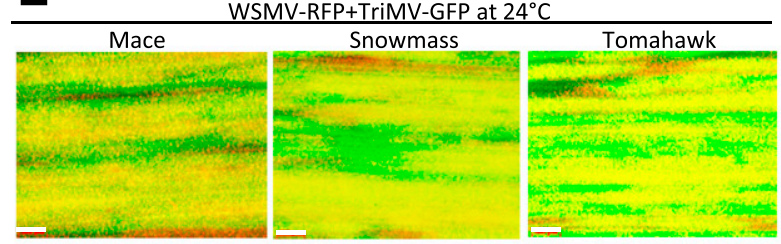

G

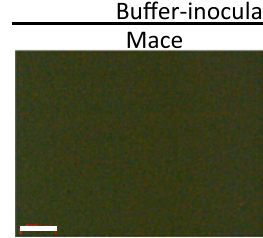

ted wheat leaves under RFP filter

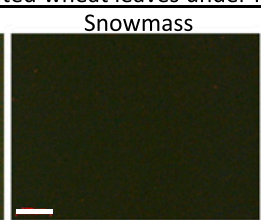

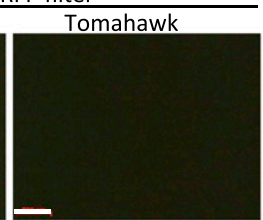

B

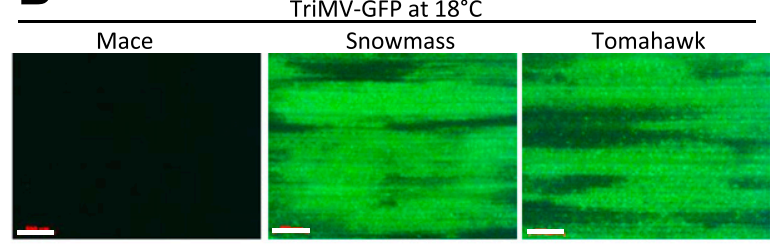

D

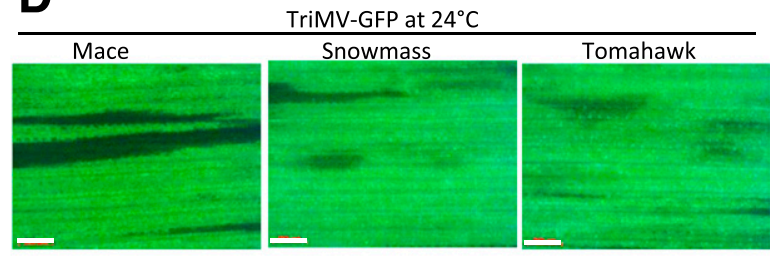

F

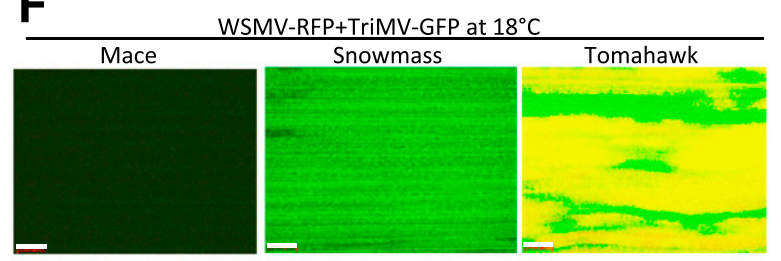

H

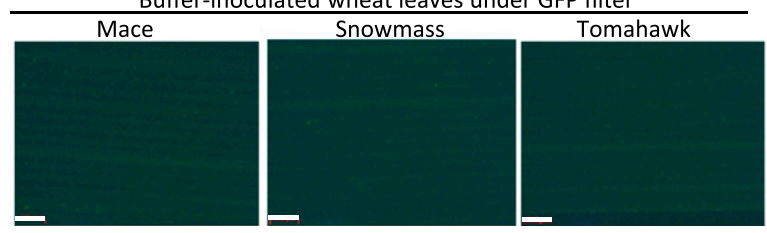

Fig. 6. Wheat streak mosaic virus (WSMV) and Triticum mosaic virus (TriMV) facilitated cultivar-specific temperature-dependent long-distance transport in resistant wheat cultivars. A and C, Systemic infection of wheat cultivars Mace, Snowmass, and Tomahawk by red fluorescent protein tagged WSMV (WSMVRFP), B and D, green fluorescent protein-tagged Triticum mosaic virus (TriMV-GFP), and E and F, WSMV-RFP+TriMV-GFP (mixed inoculation), at 21 days postinoculation (dpi) at $18^{\circ} \mathrm{C}\left(\mathrm{A}, \mathrm{B}\right.$, and F) and $24^{\circ} \mathrm{C}(\mathrm{C}, \mathrm{D}$, and E). G, Buffer-inoculated leaves of 'Mace', 'Snowmass', and 'Tomahawk' were observed under RFP or H, GFP filters as negative controls. The upper noninoculated wheat leaves were observed under a Stereo Discovery V12 fluorescence microscope using RFP or GFP narrow-band filters. Merged images of RFP and GFP from mixed inoculation are presented in E and F. Note that colocalization of RFP and GFP resulted in a yellow color. The brightness of buffer-inoculated images in G and H were adjusted to see the background of objects under RFP and GFP filters, respectively. Note that WSMV-RFP does not infect 'Mace' and 'Snowmass' systemically (A) and TriMV-GFP does not infect 'Mace' but efficiently infected 'Snowmass' at $18^{\circ} \mathrm{C}(\mathrm{B})$. 
against Potato virus $Y$ and TEV (Ruffel et al. 2005), rym4 and rym5 in barley against Barley yellow mosaic virus (Kanyuka et al. 2005; Stein et al. 2005), sbml, wlv, and cyv in pea against Pea seed-borne mosaic virus, Bean yellow mosaic virus, and Clover yellow vein virus, respectively (Bruun-Rasmussen et al. 2007; Gao et al. 2004), and bc-3 in beans against Bean common mosaic virus (Naderpour et al. 2010). Recently, Yang and associates (2014) demonstrated that loss-of-function HvPDIL5-1 alleles at the recessive ryml1 resistance locus conferred broad-spectrum resistance to several strains of bymoviruses. However, recessive virus $R$ genes are unlikely to be found in hexaploid wheat. Dominant virus $R$ genes are characterized by induction of a hypersensitive or extreme response when plants are inoculated with viruses containing the corresponding avirulence factor (Fraser 1990; Moffett 2009). However, Wsm1 and Wsm2 do not induce a hypersensitive or extreme response on inoculated wheat leaves at $18^{\circ} \mathrm{C}$, suggesting that these genes are nonconventional $R$ genes.

The other nonconventional $R$ genes also provide viral resistance by debilitating one or more steps that led to systemic infection of plants. For example, the RTM genes of Arabidopsis

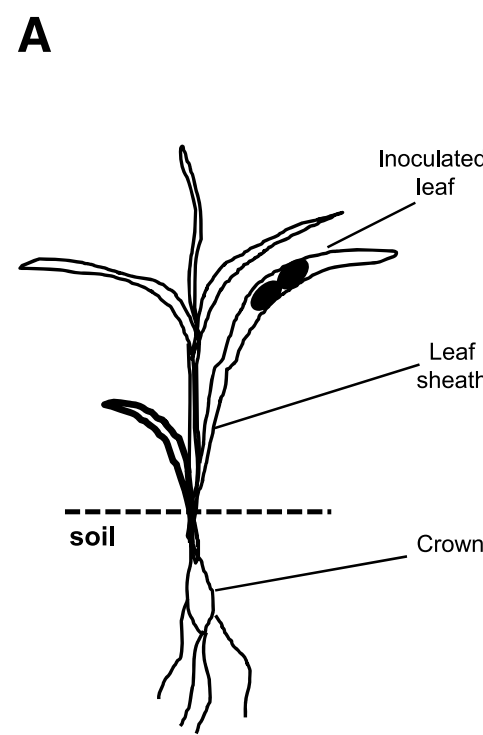

B

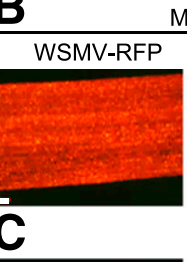

Mace TriMV-GFP
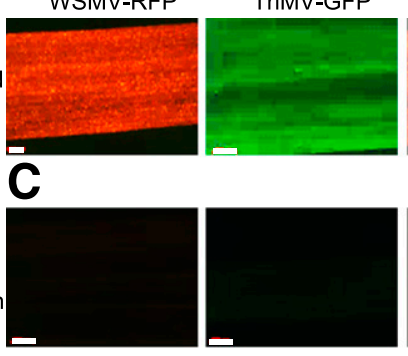

D
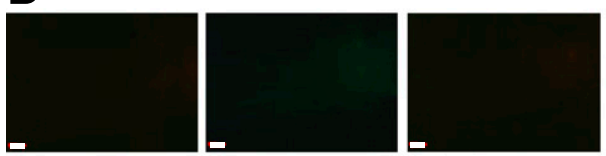

$\mathbf{E}$
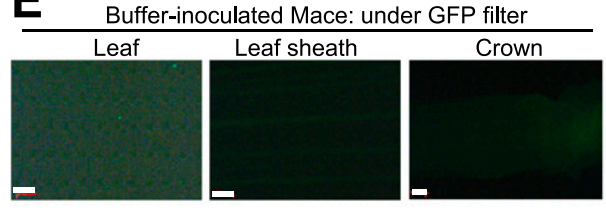

Snowmass
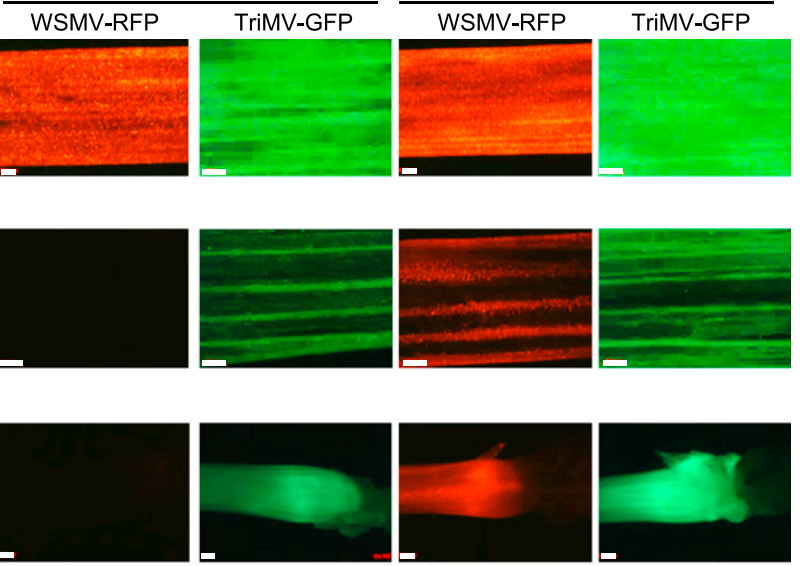
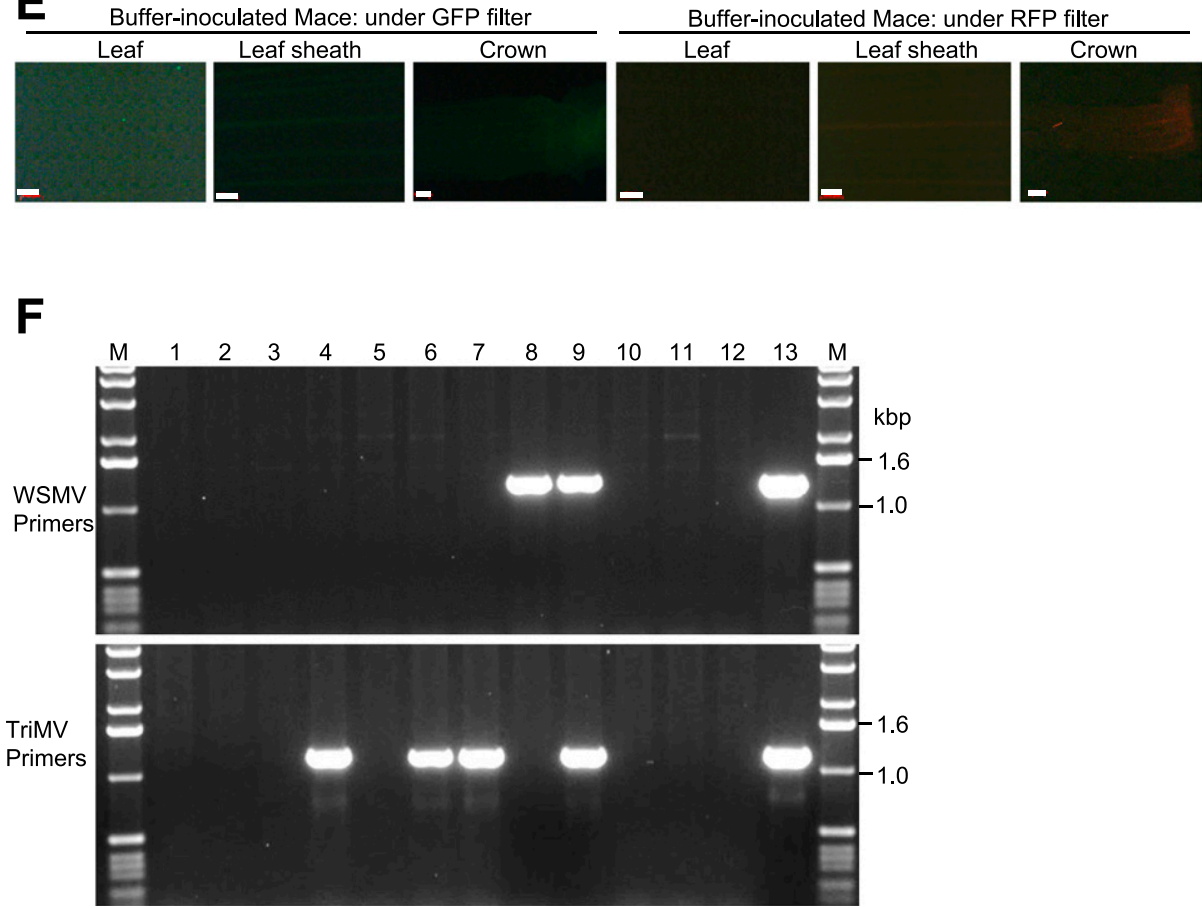

Fig. 7. Wheat streak mosaic virus (WSMV) and Triticum mosaic virus (TriMV) failed to enter the vasculature of resistant wheat cultivars at $18^{\circ} \mathrm{C}$. A, Schematic diagram of a wheat plant showing the point of inoculation (dark circles), leaf sheath, and crown. B, Local foci elicited by red fluorescent protein-tagged WSMV (WSMV-RFP) or green fluorescent protein-tagged TriMV (TriMV-GFP) in inoculated leaves of resistant ('Mace' and 'Snowmass') and susceptible ('Tomahawk') wheat at 21 days postinoculation (dpi). $\mathbf{C}$ and $\mathbf{D}$, Detection of fluorescent protein-tagged viruses in the leaf sheaths of inoculated leaves (C) and in crowns (D). Note that fluorescent protein was not observed at detectable levels in the leaf sheaths and crowns of resistant wheat cultivars but abundant levels were observed in susceptible wheat cultivars. E, Buffer-inoculated healthy leaf, leaf sheath, and crown observed under GFP or RFP narrow-band filters are shown as negative controls. The brightness of buffer-inoculated images were adjusted to see the background of objects under RFP and GFP filters. Bars represent $500 \mu \mathrm{M}$. F, Reverse transcription-polymerase chain reaction (RT-PCR) assay of total RNA isolated from wheat crowns at 21 dpi. Agarose gel electrophoresis image showing RT-PCR products of WSMV and TriMV from the crown samples of 'Mace' (lanes 1 to 3), 'Snowmass' (lanes 4 to 6), and 'Tomahawk' (lanes 7 to 9) inoculated with TriMV-GFP (lanes 1, 4, and 7), WSMV-RFP (lanes 2, 5, and 8), and coinoculated with TriMV-GFP and WSMV-RFP (lanes 3, 6, and 9). Note that WSMV and TriMV did not accumulate at detectable levels in the crowns of 'Mace' and 'Snowmass', or 'Mace', respectively. Total RNA from healthy crowns of 'Mace' (lane 10), 'Snowmass' (lane 11), and 'Tomahawk' (lane 12) was used as negative control. Total RNA from 'Tomahawk' leaves infected with WSMV (top panel, lane 13) and TriMV (bottom panel, lane 13) was used as a positive control for RT-PCR. Lane M: 1.0-kbp DNA ladder. 
prevent systemic infection but not cell-to-cell movement of TEV (Chisholm et al. 2001; Decroocq et al. 2009; Mahajan et al. 1998; Whitham et al. 2000). The Rsv4 gene of soybean restricts SMV movement and accumulation in inoculated leaves and also prevents systemic infection (Khatabi et al. 2012). The Tm-1 gene of tomato prevents the formation of viral replication complex on membrane surfaces, thus inhibiting ToMV replication (Ishibashi and Ishikawa 2013; Ishibashi et al. 2007). The above-mentioned nonconventional $R$ genes, including Wsml and Wsm2, do not elicit HR-mediated resistance but provide resistance by affecting, singly or in combination, viral replication, cell-to-cell, or long-distance movement. However, it remains to be seen whether these nonconventional dominant $R$ genes can be considered as a new class of $R$ genes.

Differential long-distance movement of viruses in a host at two temperatures with no appreciable effects on virus replication and cell-to-cell movement is unusual. It is possible that interaction of Wsml and Wsm2 gene products with viral proteins is temperature-dependent, and such interactions might be required for long-distance transport in resistant wheat cultivars. Potyviral P1, P3, 6K2, NIa-VPg, NIa-Pro, and CP have been reported to be involved in differential infection of certain hosts (Carbonell et al. 2013; Chen et al. 2008; Decroocq et al. 2009; Rajamäki and Valkonen 1999; Salvador et al. 2008; Schaad et al. 1997; Tatineni and French 2014; Tatineni et al. 2011b). In the above-mentioned examples, viral gene products are required for infection of certain specific hosts. However, the situation with WSMV and TriMV is different, as wild-type viruses exhibited temperature-dependent long-distance movement in resistant wheat cultivars. The members of family Potyviridae do not encode dedicated long-distance movement proteins (Revers and García 2015). Instead, several potyviral proteins are involved in long-distance movement in addition to other unrelated functions. Recently, the WSMV CP was determined to be a long-distance transport factor for systemic infection of maize by specifically allowing the virus to enter the vascular system (Tatineni and French 2014; Tatineni et al. $2011 \mathrm{~b}$ ). These data suggest that the $\mathrm{N}$ - and $\mathrm{C}$-terminal regions of CP may be involved in interactions with the host proteins for a successful invasion of hosts by WSMV. Viral determinants for long-distance movement of TriMV are not known. However, availability of TriMV infectious cDNA clone (Tatineni et al. 2015) will facilitate determination of viral determinants for longdistance movement.

Viruses establish successful systemic infection in a host plant by performing repeated cycles of cell-to-cell movement through plasmodesmata and long-distance transport by entry and exit through the vasculature. Since viruses encode only a limited number of proteins, viruses must interact with several host factors to survive in plant hosts. Incompatible interactions between viral and host factors at any of these steps could prevent viruses from infecting plants systemically. In this study, both WSMV and TriMV efficiently replicated and moved cell to cell in resistant wheat cultivars but failed to move long distance at $18^{\circ} \mathrm{C}$, indicating that incompatible interactions between viral and host factors for long-distance transport as the most likely explanation for resistance. It is interesting that nonallelic Wsm1 and Wsm2 genes elicit resistance in wheat cultivars with a similar mechanism of specifically blocking viral long-distance transport at $18^{\circ} \mathrm{C}$ but not at higher temperatures.

Though several host factors restricting viral long-distance movement process were genetically identified (Mandadi and Scholthof 2013; Revers and Nicaise 2014), only the RTM genes from Arabidopsis were cloned and characterized (Cosson et al. 2010; Mahajan et al. 1998; Whitham et al. 2000). Although both Arabidopsis RTM genes and wheat Wsm1 and Wsm2 genes provide resistance by blocking virus long-distance movement, the Wsm-based resistance differs from that of RTM as Wsmbased resistance is strictly temperature sensitive. The Wsmbased resistance blocking viral long-distance transport at $18^{\circ} \mathrm{C}$ might be due to the following reasons: i) sequestration of one or both virus particles or ribonucleoprotein complex while loading into the vasculature, ii) the Wsm-gene products limit accessibility of host factors for virus long-distance transport, or iii) expression of host proteins required for viral long-distance transport were silenced or expressed at suboptimal levels at $18^{\circ} \mathrm{C}$. The fact that both WSMV and TriMV efficiently infected resistant wheat cultivars at higher temperatures suggests that incompatible interactions between viral and host factors at $18^{\circ} \mathrm{C}$, temperaturedependent expression of Wsml and Wsm2 genes in wheat, or the silencing or low-level expression of Wsm genes encoded host factors for viral long-distance transport result in Wsm-based resistance in wheat cultivars.

\section{MATERIALS AND METHODS}

\section{Wheat cultivars.}

Wheat cvs. Mace (PI 651043) (Graybosch et al. 2009) and Snowmass (PI 658597) (Haley et al. 2011), containing the Wsm1 and Wsm2 genes, respectively, and cv. Tomahawk (PI 552814), a susceptible cultivar, were used in this investigation. PI numbers indicate accession designations of these cultivars in the United States Department of Agriculture (USDA)-Agricultural Research Service National Small Grains Collection, Aberdeen, ID, U.S.A.

\section{Construction of RFP-tagged WSMV.}

The RFP ORF was fused to the heptapeptide cleavage site located between the 6K1/CI cistrons by overlap extension PCR (Ho et al. 1989). The RFP ORF with a cleavage peptide sequence at its $3^{\prime}$ end was precisely inserted between the P1 and HC-Pro cistrons by overlap extension PCR, using three individual PCR fragments with 18- to 21-bp overlapping sequences as described (Tatineni et al. 2011a). Briefly, PCR fragment 1 contained the SP6 RNA polymerase promoter sequence, followed by WSMV sequence through the end of P1 cistron plus the first six codons of RFP. PCR fragment 2 contained the last six codons of P1, followed by RFP ORF with a cleavage site plus the first seven codons of HC-Pro. PCR fragment 3 comprised the last seven codons of RFP, followed by a cleavage site plus the HC-Pro cistron and part of the P3 cistron sequence until nucleotide 3,960. Overlap extension PCR was performed with gel-eluted PCR fragments 1, 2, and 3 as templates. Amplification of PCR fragments 1 to 3 and overlap extension PCR were performed with Herculase II Fusion DNA polymerase (Agilent Technologies, Santa Clara, CA, U.S.A.). The overlap extension PCR fragments were digested with NgoMIV (engineered upstream of an SP6 RNA polymerase promoter sequence in the plus-sense primer) and $A f l I I$ (nucleotide 3,905) and were ligated into similarly digested pSP6-WSMV (Choi et al. 1999).

\section{Viruses.}

Wild-type WSMV isolate Sidney 81 and TriMV isolate Nebraska were obtained from in vitro transcripts of pSP6WSMV (Choi et al. 1999) and pTriMV-R (Tatineni et al. 2015), respectively. Cycle 3 GFP-tagged TriMV (pTriMV-GFP-NIb/CP [9aa]) was described previously (Tatineni et al. 2015). In vitro transcripts of pSP6-WSMV-RFP-6K1/CI(7aa) and pTriMV-GFP$\mathrm{NIb} / \mathrm{CP}(9 \mathrm{aa})$ were inoculated to wheat seedlings to obtain WSMVRFP and TriMV-GFP, respectively.

In vitro transcription reaction of each construct was carried out in a $40-\mu l$ reaction volume consisting of $1.0 \mu \mathrm{g}$ of linearized plasmid DNA, $40 \mathrm{mM}$ Tris- $\mathrm{HCl}, \mathrm{pH}$ 7.9, $20 \mathrm{mM}$ dithiothreitol, 
$8.5 \mathrm{mM} \mathrm{MgCl}_{2}, 2 \mathrm{mM}$ spermidine, $1.2-\mathrm{mM}$ concentrations each of ATP, CTP, UTP, and Cap analog (m7G[5']ppp[5']G; Cellscript, Madison, WI, U.S.A.), $0.048 \mathrm{mM} \mathrm{GTP,} 20 \mathrm{U}$ of rRNasin ribonuclease inhibitor (Promega) and $50 \mathrm{U}$ of SP6 RNA polymerase $\left(\right.$ Cellscript $\left.^{\mathrm{TM}}\right)$. The reaction was incubated for $15 \mathrm{~min}$ at $37^{\circ} \mathrm{C}$. The concentration of GTP was increased to $0.5 \mathrm{mM}$ with additional 2 -h incubation at $37^{\circ} \mathrm{C}$. The integrity and quality of transcripts was examined by analyzing $1 \mu \mathrm{l}$ of in vitro transcripts on $1.0 \%$ native agarose gel in $1 \times$ Tris-acetateEDTA (TAE) buffer. Freshly prepared in vitro transcripts were inoculated to wheat seedlings at the single leaf stage as described (Tatineni et al. 2011b). Infected wheat leaves collected at $14 \mathrm{dpi}$ were stored at $-20^{\circ} \mathrm{C}$ for inoculation of wheat seedlings.

\section{Screening wheat cultivars for virus resistance.}

Frozen wheat leaves infected with WSMV or TriMV at 14 dpi were ground in $20 \mathrm{mM}$ sodium phosphate buffer, $\mathrm{pH} 7.0$, at 1: 20 dilution $(1 \mathrm{~g}$ per $19 \mathrm{ml})$ with a mortar and pestle. Wheat plants were raised in a pasteurized soil mix that consisted of $33 \%$ each of clay loam soil and peat moss and $16.5 \%$ each of sand and vermiculite. Wheat cvs. Mace, Snowmass, and Tomahawk at the two-leaf stage were mechanically inoculated with WSMV or TriMV (approximately 20 seedlings per $15-\mathrm{cm}$ earthen pot). Two inoculated pots per cultivar per virus were incubated in the greenhouse at a mean temperature of $24^{\circ} \mathrm{C}$ $\left(20^{\circ} \mathrm{C}\right.$ minimum and $26^{\circ} \mathrm{C}$ maximum temperatures) with $14 \mathrm{~h}$ of daylight or supplemental light. Another set of inoculated wheat seedlings (two pots per cultivar per virus) was incubated in a growth chamber at $18^{\circ} \mathrm{C}$ with $14 \mathrm{~h}$ of light. Wheat plants were observed for symptom development at 14 and $21 \mathrm{dpi}$.

\section{Examination of virus movement.}

Two sets of wheat seedlings were mechanically inoculated at the two-leaf stage with crude sap of WSMV-RFP, TriMV-GFP, or both at a 1:20 dilution in $20 \mathrm{mM}$ sodium phosphate buffer, $\mathrm{pH}$ 7.0. One set of inoculated plants were incubated at $18^{\circ} \mathrm{C}$ in a growth chamber and another set in a greenhouse at a mean temperature of $24^{\circ} \mathrm{C}$ with $14 \mathrm{~h}$ of light. Cell-to-cell movement of WSMV-RFP and TriMV-GFP was monitored by examining the formation of fluorescent foci on inoculated wheat leaves under a Zeiss Stereo Discovery V12 fluorescence microscope, using narrow band filter sets of RFP or GFP, as described (Tatineni et al. 2011a). The fluorescent images were taken with an AxioCam MRc5 camera attached to the V12 fluorescence microscope using an RFP filter set 43 (533 to $558 \mathrm{~nm}$ excitation and 571 to $641 \mathrm{~nm}$ emission) or GFP filter set 38 (400 to $450 \mathrm{~nm}$ excitation and 450 to $490 \mathrm{~nm}$ emission) (Carl Zeiss MicroImaging, Inc., New York), as described (Tatineni et al. 2011a, 2015). The fluorescent foci sizes were measured using a program provided with the AxioCam MRc5 camera. Longdistance movement of WSMV-RFP and TriMV-GFP in wheat cultivars was examined in upper noninoculated leaves by observing for the presence of RFP or GFP fluorescence.

\section{Quantification of genomic RNAs of WSMV and TriMV.}

Total RNA was extracted from inoculated wheat leaves using Tripure reagent, as described (Tatineni et al. 2010). One microgram of total RNA was used to synthesize the first-strand cDNA, using random primers. One microliter of 1:10-diluted first-strand cDNA reaction was used for real-time PCR, using primers and probe as described by Tatineni et al. (2010).

\section{RT-PCR assay.}

Total RNA was extracted from upper fully expanded wheat leaves and crowns, as described (McNeil et al. 1996). The firststrand cDNA was synthesized in a $10-\mu$ reaction volume with random primers, as described previously (Tatineni et al. 2010).
One microliter of first-strand cDNA was used for PCR, in a $25-\mu$ reaction volume with plus- and minus-sense $\mathrm{CP}$-specific primers of WSMV (Tatineni et al. 2014) or TriMV (Bartels et al. 2016), with the following PCR program: $95^{\circ} \mathrm{C}$ for $2 \mathrm{~min}$, followed by 30 cycles at $95^{\circ} \mathrm{C}$ for $30 \mathrm{~s}, 52^{\circ} \mathrm{C}$ for $30 \mathrm{~s}$, and $72^{\circ} \mathrm{C}$ for $90 \mathrm{~s}$ and one cycle at $72^{\circ} \mathrm{C}$ for $10 \mathrm{~min}$. The RT-PCR products were analyzed on $1.0 \%$ agarose gels in TAE buffer.

\section{Data analyses.}

Data analyses were performed using SAS software version 9.4 (SAS Institute Inc. Cary, NC, U.S.A.). Number of foci and foci size was tested for differences using PROC GLIMMIX with Poisson and normal distribution, respectively. Genomic RNA molecule data were log transformed and were tested for differences by using PROC GLIMMIX, but nontransformed data were reported. The LSMEANS statement was used to obtain least squares means and the Tukey-Kramer test at $P=$ 0.05 was used for pairwise comparison of treatment means. Means and standard errors for numbers of foci, foci size, and genomic RNA molecules were obtained using the PROC MEANS.

\section{ACKNOWLEDGMENTS}

We thank R. French and M. R. Hajimorad for critical reading of the manuscript, S. D. Haley for providing wheat cv. Snowmass seed, and J. Horrell for technical assistance. This project was supported, in part, by funds provided through the USDA, USDA-National Institute of Food and Agriculture grant number 2013-68004-20358.

\section{LITERATURE CITED}

Bartels, M., French, R., Graybosch, R. A., and Tatineni, S. 2016. Triticum mosaic virus exhibits limited population variation yet shows evidence of parallel evolution after replicated serial passage in wheat. Virology 492: 92-100.

Bendahmane, A., Kanyuka, K., and Baulcombe, D. C. 1999. The $R x$ gene from potato controls separate virus resistance and cell death responses. Plant Cell 11:781-792.

Benitez-Alfonso, Y., Faulkner, C., Ritzenthaler, C., and Maule, A. J. 2010 Plasmodesmata: Gateways to local and systemic virus infection. Mol. Plant-Microbe Interact. 23:1403-1412.

Brakke, M. K. 1987. Virus disease in wheat. Pages 585-603 in: Wheat and Wheat Improvement, 2nd Ed., E. G. Heyne, ed. American Society of Agronomy, Crop Science Society of America, Soil Science Society of America, Madison, WI, U.S.A.

Bruun-Rasmussen, M., Møller, I. S., Tulinius, G., Hansen, J. K. R., Lund, O. S., and Johansen, I. E. 2007. The same allele of translation initiation factor 4E mediates resistance against two Potyvirus spp. in Pisum sativum. Mol. Plant-Microbe Interact. 20:1075-1082.

Burrows, M., Franc, G., Rush, C., Blunt, T., Ito, D., Kinzer, K., Olson, J., O'Mara, J., Price, J., Tande, C., Ziems, A., and Stack, J. 2009 Occurrence of viruses in wheat in the Great Plains region, 2008. Plant Health Prog. Published online. doi:10.1094/PHP-2009-0706-01-RS

Byamukama, E., Seifers, D. L., Hein, G. L., De Wolf, E., Tisserat, N. A., Langham, M. A. C., Osborne, L. E., Timmerman, A., and Wegulo, S. N. 2013. Occurrence and distribution of Triticum mosaic virus in the central Great Plains. Plant Dis. 97:21-29.

Byamukama, E., Tatineni, S., Hein, G. L., Graybosch, R. A., Baenziger, P. S., French, R., and Wegulo, S. N. 2012. Effects of single and double infections of winter wheat by Triticum mosaic virus and Wheat streak mosaic virus on yield determinants. Plant Dis. 96:859-864.

Byamukama, E., Tatineni, S., Hein, G. L., Graybosch, R. A., Baenziger, P. S., French, R. C., and Wegulo, S. N. 2014. Quantification of yield loss caused by Triticum mosaic virus and Wheat streak mosaic virus in winter wheat under field conditions. Plant Dis. 98:127-133.

Campbell, R. E., Tour, O., Palmer, A. E., Steinbach, P. A., Baird, G. S., Zacharias, D. A., and Tsien, R. Y. 2002. A monomeric red fluorescent protein. Proc. Natl. Acad. Sci. U.S.A. 99:7877-7882.

Carbonell, A., Maliogka, V. I., Pérez, Jde. J., Salvador, B., León, D. S., García, J. A., and Simón-Mateo, C. 2013. Diverse amino acid changes at specific positions in the $\mathrm{N}$-terminal region of the coat protein allow $\mathrm{Plum}$ pox virus to adapt to new hosts. Mol. Plant-Microbe Interact. 26:1211-1224.

Chen, K. C., Chiang, C. H., Raja, J. A., Liu, F. L., Tai, C. H., and Yeh, S. D. 2008. A single amino acid of niapro of Papaya ringspot virus determines 
host specificity for infection of papaya. Mol. Plant-Microbe Interact. 21: 1046-1057.

Chisholm, S. T., Parra, M. A., Anderberg, R. J., and Carrington, J. C. 2001. Arabidopsis RTM1 and RTM2 genes function in phloem to restrict longdistance movement of Tobacco etch virus. Plant Physiol. 127:1667-1675.

Choi, I. R., French, R., Hein, G. L., and Stenger, D. C. 1999. Fully biologically active in vitro transcripts of the eriophyid mite-transmitted Wheat streak mosaic tritimovirus. Phytopathology 89:1182-1185.

Choi, I. R., Horken, K. M., Stenger, D. C., and French, R. 2005. An internal RNA element in the P3 cistron of Wheat streak mosaic virus revealed by synonymous mutations that affect both movement and replication. J. Gen. Virol. 86:2605-2614.

Cosson, P., Sofer, L., Le, Q. H., Léger, V., Schurdi-Levraud, V., Whitham, S. A., Yamamoto, M. L., Gopalan, S., Le Gall, O., Candresse, T., Carrington, J. C., and Revers, F. 2010. RTM3, which controls longdistance movement of potyviruses, is a member of a new plant gene family encoding a meprin and TRAF homology domain-containing protein. Plant Physiol. 154:222-232.

de Ronde, D., Butterbach, P., and Kormelink, R. 2014. Dominant resistance against plant viruses. Front. Plant Sci. 5:307.

Decroocq, V., Salvador, B., Sicard, O., Glasa, M., Cosson, P., SvanellaDumas, L., Revers, F., García, J. A., and Candresse, T. 2009. The determinant of potyvirus ability to overcome the RTM resistance of Arabidopsis thaliana maps to the $\mathrm{N}$-terminal region of the coat protein. Mol. Plant-Microbe Interact. 22:1302-1311.

Fellers, J. P., Seifers, D., Ryba-White, M., and Martin, T. J. 2009. The complete genome sequence of Triticum mosaic virus, a new wheatinfecting virus of the high plains. Arch. Virol. 154:1511-1515.

Fraser, R. S. S. 1990. The genetics of resistance to plant viruses. Annu. Rev. Phytopathol. 28:179-200.

French, R., and Stenger, D. C. 2004. Wheat streak mosaic virus. Pages 602-604 in: Viruses and Virus Diseases of Poaceae. H. Lapierre, and P. Signoret, eds. INRA Editions, Paris.

Fukuda, H., Arai, M., and Kuwajima, K. 2000. Folding of green fluorescent protein and the cycle 3 mutant. Biochemistry 39:12025-12032.

Gao, Z., Eyers, S., Thomas, C., Ellis, N., and Maule, A. 2004. Identification of markers tightly linked to $s b m$ recessive genes for resistance to Pea seed-borne mosaic virus. Theor. Appl. Genet. 109:488-494.

Graybosch, R. A., Peterson, C. J., Baenziger, P. S., Baltensperger, D. D., Nelson, L. A., Jin, Y., Kolmer, J., Seaborn, B., French, R., Hein, G., Martin, T. J., Beecher, B., Schwarzacher, T., and Heslop-Harrison, P. 2009. Registration of 'Mace' hard red winter wheat. J. Plant Regist. 3: 51-56.

Hajimorad, M. R., Eggenberger, A. L., and Hill, J. H. 2005. Loss and gain of elicitor function of Soybean mosaic virus G7 provoking Rsv1-mediated lethal systemic hypersensitive response maps to P3. J. Virol. 79: 1215-1222.

Hajimorad, M. R., Eggenberger, A. L., and Hill, J. H. 2006. Strain-specific P3 of Soybean mosaic virus elicits Rsv1-mediated extreme resistance, but absence of P3 elicitor function alone is insufficient for virulence on Rsv1-genotype soybean. Virology 345:156-166.

Haley, S. D., Johnson, J. J., Peairs, F. B., Stromberger, J. A., Heaton, E. E., Seifert, S. A., Kottke, R. A., Rudolph, J. B., Martin, T. J., Bai, G., Chen, X., Bowden, R. L., Jin, Y., Kolmer, J. A., Seifers, D. L., Chen, M., and Seabourn, B. W. 2011. Registration of 'Snowmass' wheat. J. Plant Regist. 5:87-90.

Haley, S. D., Martin, T. J., Quick, J. S., Seifers, D. L., Stromberger, J. A., Clayshulte, S. R., Clifford, B. L., Peairs, F. B., Rudolph, J. B., Johnson, J. J., Gill, B. S., and Friebe, B. 2002. Registration of CO960293-2 wheat germplasm resistant to Wheat streak mosaic virus and Russian wheat aphid. Crop Sci. 42:1381-1382.

Harries, P., and Ding, B. 2011. Cellular factors in plant virus movement: At the leading edge of macromolecular trafficking in plants. Virology 411: 237-243.

Heinlein, M. 2015. Plant virus replication and movement. Virology 479480:657-671.

Ho, S. N., Hunt, H. D., Horton, R. M., Pullen, J. K., and Pease, L. R. 1989. Site-directed mutagenesis by overlap extension using the polymerase chain reaction. Gene 77:51-59.

Ingvardsen, C. R., Xing, Y., Frei, U. K., and Lübberstedt, T. 2010. Genetic and physical fine mapping of Scmv2, a potyvirus resistance gene in maize. Theor. Appl. Genet. 120:1621-1634.

Ishibashi, K., and Ishikawa, M. 2013. The resistance protein Tm-1 inhibits formation of a Tomato mosaic virus replication protein-host membrane protein complex. J. Virol. 87:7933-7939.

Ishibashi, K., Masuda, K., Naito, S., Meshi, T., and Ishikawa, M. 2007. An inhibitor of viral RNA replication is encoded by a plant resistance gene. Proc. Natl. Acad. Sci. U.S.A. 104:13833-13838.
Jones, J. D. G., and Dangl, J. L. 2006. The plant immune system. Nature 444:323-329.

Jones, M. W., Boyd, E. C., and Redinbaugh, M. G. 2011. Responses of maize (Zea mays L.) near isogenic lines carrying Wsm1, Wsm2, and Wsm3 to three viruses in the Potyviridae. Theor. Appl. Genet. 123: 729-740.

Kang, B.-C., Yeam, I., Frantz, J. D., Murphy, J. F., and Jahn, M. M. 2005b. The pvr1 locus in Capsicum encodes a translation initiation factor eIF4E that interacts with Tobacco etch virus VPg. Plant J. 42:392-405.

Kang, B.-C., Yeam, I., and Jahn, M. M. 2005a. Genetics of plant virus resistance. Annu. Rev. Phytopathol. 43:581-621.

Kanyuka, K., Druka, A., Caldwell, D. G., Tymon, A., McCallum, N., Waugh, R., and Adams, M. J. 2005. Evidence that the recessive bymovirus resistance locus rym 4 in barley corresponds to the eukaryotic translation initiation factor 4E gene. Mol. Plant Pathol. 6:449-458.

Khatabi, B., Fajolu, O. L., Wen, R.-H., and Hajimorad, M. R. 2012. Evaluation of North American isolates of Soybean mosaic virus for gain of virulence on $R s v$-genotype soybeans with special emphasis on resistancebreaking determinants on Rsv4. Mol. Plant Pathol. 13:1077-1088.

Lu, H., Price, J., Devkota, R., Rush, C., and Rudd, J. 2011. A dominant gene for resistance to Wheat streak mosaic virus in winter wheat line CO960293-2. Crop Sci. 51:5-12.

Mahajan, S. K., Chisholm, S. T., Whitham, S. A., and Carrington, J. C. 1998. Identification and characterization of a locus (RTM1) that restricts long-distance movement of tobacco etch virus in Arabidopsis thaliana. Plant J. 14:177-186.

Mandadi, K. K., and Scholthof, K.-B. G. 2013. Plant immune responses against viruses: How does a virus cause disease? Plant Cell 25:1489-1505.

Mazier, M., Flamain, F., Nicolai, M., Sarnette, V., and Caranta, C. 2011. Knock-down of both eIF4E1 and eIF4E2 genes confers broad-spectrum resistance against potyviruses in tomato. PLoS One 6:e29595.

McMechan, A. J., Tatineni, S., French, R., and Hein, G. L. 2014. Differential transmission of Triticum mosaic virus by wheat curl mite populations collected in the Great Plains. Plant Dis. 98:806-810.

McMullen, M. D., Jones, M. W., Simcox, K. D., and Louie, R. 1994. Three genetic loci control resistance to Wheat streak mosaic virus in the maize in bred P1405. Mol. Plant-Microbe Interact. 7:708-712.

McNeil, J. E., French, R., Hein, G. L., Baenziger, P. S., and Eskridge, K. M. 1996. Characterization of genetic variability among natural populations of Wheat streak mosaic virus. Phytopathology 86:1222-1227.

Moffett, P. 2009. Mechanisms of recognition in dominant $R$ gene mediated resistance. Adv. Virus Res. 75:1-33.

Naderpour, M., Lund, O. S., Larsen, R., and Johansen, E. 2010. Potyviral resistance derived from cultivars of Phaseolus vulgaris carrying $b c-3$ is associated with the homozygotic presence of a mutated $e I F 4 E$ allele. Mol. Plant Pathol. 11:255-263.

Nelson, R. S., and Citovsky, V. 2005. Plant viruses. Invaders of cells and pirates of cellular pathways. Plant Physiol. 138:1809-1814.

Nicaise, V., German-Retana, S., Sanjuán, R., Dubrana, M.-P., Mazier, M., Maisonneuve, B., Candresse, T., Caranta, C., and LeGall, O. 2003. The eukaryotic translation initiation factor $4 \mathrm{E}$ controls lettuce susceptibility to the Potyvirus Lettuce mosaic virus. Plant Physiol. 132:1272-1282.

Rajamäki, M. L., and Valkonen, J. P. T. 1999. The 6K2 protein and the VPg of Potato virus A are determinants of systemic infection in Nicandra physaloides. Mol. Plant-Microbe Interact. 12:1074-1081.

Revers, F., and García, J. A. 2015. Molecular biology of potyviruses. Adv. Virus Res. 92:101-199.

Revers, F., and Nicaise, N. 2014. Plant resistance to infection by viruses. In: eLS. Published online. John Wiley \& Sons, Ltd., Chichester, U.K.

Ruffel, S., Dussault, M.-H., Palloix, A., Moury, B., Bendahmane, A., Robaglia, C., and Caranta, C. 2002. A natural recessive resistance gene against potato virus $Y$ in pepper corresponds to the eukaryotic initiation factor 4E (eIF4E). Plant J. 32:1067-1075.

Ruffel, S., Gallois, J. L., Lesage, M. L., and Caranta, C. 2005. The recessive potyvirus resistance gene pot 1 is the tomato orthologue of the pepper pvr2-eIF4E gene. Mol. Genet. Genomics 274:346-353.

Ruffel, S., Gallois, J. L., Moury, B., Robaglia, C., Palloix, A., and Caranta, C. 2006. Simultaneous mutations in translation initiation factors eIF4E and $\mathrm{eIF}$ (iso)4E are required to prevent pepper veinal mottle virus infection of pepper. J. Gen. Virol. 87:2089-2098.

Saghai Maroof, M. A., Tucker, D. M., Skoneczka, J. A., Bowman, B. C., Tripathy, S., and Tolin, S. A. 2010. Fine mapping and candidate gene discovery of the Soybean mosaic virus resistance gene, Rsv4. Plant Genome 3:14-22.

Salvador, B., Delgadillo, M. O., Sáenz, P., García, J. A., and SimónMateo, C. 2008. Identification of Plum pox virus pathogenicity determinants in herbaceous and woody hosts. Mol. Plant-Microbe Interact. 21:20-29. 
Schaad, M. C., Lellis, A. D., and Carrington, J. C. 1997. VPg of tobacco etch potyvirus is a host genotype-specific determinant for long-distance movement. J. Virol. 71:8624-8631.

Seifers, D. L., Martin, T. J., Harvey, T. L., Fellers, J. P., and Michaud, J. P. 2009. Identification of the wheat curl mite as the vector of Triticum mosaic virus. Plant Dis. 93:25-29.

Seifers, D. L., Martin, T. J., Harvey, T. L., Fellers, J. P., Stack, J. P., RybaWhite, M., Haber, S., Krokhin, O., Spicer, V., Lovat, N., Yamchuk, A., and Standing, K. G. 2008. Triticum mosaic virus: A new virus isolated from wheat in Kansas. Plant Dis. 92:808-817.

Seifers, D. L., Martin, T. J., Harvey, T. L., and Gill, B. S. 1995. Temperaturesensitivity and efficacy of Wheat streak mosaic virus resistance derived from Agropyron intermedium. Plant Dis. 79:1104-1106.

Seifers, D. L., Martin, T. J., Harvey, T. L., and Haber, S. 2007. Temperaturesensitive Wheat streak mosaic virus resistance identified in KS03HW12 wheat. Plant Dis. 91:1029-1033.

Slykhuis, J. T. 1955. Aceria tulipae Keifer (Acarina: Eriophyidae) in relation to spread of wheat streak mosaic virus. Phytopathology 45:116-128.

Stein, N., Perovic, D., Kumlehn, J., Pellio, B., Stracke, S., Streng, S., Ordon, F., and Graner, A. 2005. The eukaryotic translation initiation factor $4 \mathrm{E}$ confers multiallelic recessive Bymovirus resistance in Hordeum vulgare (L.). Plant J. 42:912-922.

Stenger, D. C., French, R., and Gildow, F. E. 2005a. Complete deletion of Wheat streak mosaic virus HC-Pro: A null mutant is viable for systemic infection. J. Virol. 79:12077-12080.

Stenger, D. C., Hall, J. S., Choi, I. R., and French, R. 1998. Phylogenetic relationships within the family potyviridae: Wheat streak mosaic virus and brome streak mosaic virus are not members of the genus Rymovirus. Phytopathology 88:782-787.

Stenger, D. C., Hein, G. L., and French, R. 2006. Nested deletion analysis of Wheat streak mosaic virus HC-Pro: Mapping of domains affecting polyprotein processing and eriophyid mite transmission. Virology 350: 465-474.

Stenger, D. C., Hein, G. L., Gildow, F. E., Horken, K. M., and French, R. 2005b. Plant virus HC-Pro is a determinant of eriophyid mite transmission. J. Virol. 79:9054-9061.

Tatineni, S., and French, R. 2014. The C-terminus of Wheat streak mosaic virus coat protein is involved in differential infection of wheat and maize through host-specific long-distance transport. Mol. Plant-Microbe Interact. 27:150-162.

Tatineni, S., Graybosch, R. A., Hein, G. L., Wegulo, S. N., and French, R. 2010. Wheat cultivar-specific disease synergism and alteration of virus accumulation during co-infection with Wheat streak mosaic virus and Triticum mosaic virus. Phytopathology 100:230-238.

Tatineni, S., Kovacs, F., and French, R. 2014. Wheat streak mosaic virus infects systemically despite extensive coat protein deletions: Identification of virion assembly and cell-to-cell movement determinants. J. Virol. 88:1366-1380.

Tatineni, S., McMechan, A. J., Bartels, M., Hein, G. L., and Graybosch, R. A. 2015. In vitro transcripts of wild-type and fluorescent proteintagged Triticum mosaic virus (family Potyviridae) are biologically active in wheat. Phytopathology 105:1496-1505.
Tatineni, S., McMechan, A. J., Hein, G. L., and French, R. 2011a. Efficient and stable expression of GFP through Wheat streak mosaic virus-based vectors in cereal hosts using a range of cleavage sites: Formation of dense fluorescent aggregates for sensitive virus tracking. Virology 410:268-281.

Tatineni, S., Qu, F., Li, R., Morris, T. J., and French, R. 2012. Triticum mosaic poacevirus enlists $\mathrm{P} 1$ rather than HC-Pro to suppress RNA silencing-mediated host defense. Virology 433:104-115.

Tatineni, S., Van Winkle, D. H., and French, R. 2011b. The N-terminal region of wheat streak mosaic virus coat protein is a host- and strainspecific long-distance transport factor. J. Virol. 85:1718-1731.

Tatineni, S., Ziems, A. D., Wegulo, S. N., and French, R. 2009. Triticum mosaic virus: A distinct member of the family potyviridae with an unusually long leader sequence. Phytopathology 99:943-950.

Truniger, V., and Aranda, M. A. 2009. Recessive resistance to plant viruses. Adv. Virus Res. 75:119-159.

Voinnet, O., Pinto, Y. M., and Baulcombe, D. C. 1999. Suppression of gene silencing: A general strategy used by diverse DNA and RNA viruses of plants. Proc. Natl. Acad. Sci. U.S.A. 96:14147-14152.

Waigmann, E., Ueki, S., Trutnyeva, K., and Citovsky, V. 2004. The ins and outs of nondestructive cell-to-cell and systemic movement of plant viruses. CRC Crit. Rev. Plant Sci. 23:195-250.

Wang, A., and Krishnaswamy, S. 2012. Eukaryotic translation initiation factor 4E-mediated recessive resistance to plant viruses and its utility in crop improvement. Mol. Plant Pathol. 13:795-803.

Wang, H. L., Wang, Y., Giesman-Cookmeyer, D., Lommel, S. A., and Lucas, W. J. 1998. Mutations in viral movement protein alter systemic infection and identify an intercellular barrier to entry into the phloem long-distance transport system. Virology 245:75-89.

Whitham, S. A., Anderberg, R. J., Chisholm, S. T., and Carrington, J. C. 2000. Arabidopsis RTM2 gene is necessary for specific restriction of tobacco etch virus and encodes an unusual small heat shock-like protein. Plant Cell 12:569-582.

Wittmann, S., Chatel, H., Fortin, M. G., and Laliberté, J.-F. 1997. Interaction of the viral protein genome linked of Turnip mosaic potyvirus with the translational eukaryotic initiation factor (iso) 4E of Arabidopsis thaliana using the yeast two-hybrid system. Virology 234:84-92.

Xoconostle-Cázares, B., Ruiz-Medrano, R., and Lucas, W. J. 2000. Proteolytic processing of $\mathrm{CmPP} 36$, a protein from the cytochrome $\mathrm{b}(5)$ reductase family, is required for entry into the phloem translocation pathway. Plant J. 24:735-747.

Yang, P., Lüpken, T., Habekuss, A., Hensel, G., Steuernagel, B., Kilian, B., Ariyadasa, R., Himmelbach, A., Kumlehn, J., Scholz, U., Ordon, F., and Stein, N. 2014. PROTEIN DISULFIDE ISOMERASE LIKE 5-1 is a susceptibility factor to plant viruses. Proc. Natl. Acad. Sci. U.S.A. 111: 2104-2109.

Yeam, I., Cavatorta, J. R., Ripoll, D. R., Kang, B. C., and Jahn, M. M. 2007. Functional dissection of naturally occurring amino acid substitutions in eIF4E that confers recessive potyvirus resistance in plants. Plant Cell 19: 2913-2928.

Young, B. A., Stenger, D. C., Qu, F., Morris, T. J., Tatineni, S., and French, R. 2012. Tritimovirus P1 functions as a suppressor of RNA silencing and an enhancer of disease symptoms. Virus Res. 163:672-677. 